\title{
Assessment of the Effect of Visual Discrimination Training in the Recognition of Letters on Reading Among Struggling Readers in Primary School in the Buea Municipality
}

\author{
Yolle Mukete Jeannette \\ B.Ed., M.Ed., $\mathrm{PhD}$ \\ University of Buea, Buea, Cameroon
}

\begin{abstract}
The desire to develop the full potentials of all learners has been the utmost concern of Special Education. This study was out to investigate the effect of visual discrimination training on reading among struggling readers in primary five in the Buea Municipality. It made use of three primary schools (government, mission and private) in a quasi-experimental study. Twenty-four struggling readers were used to verify if visual discrimination training on letter, word, number, geometric shapes and pictures recognition has any effect on their reading ability. They were selected sequentially through teacher nomination, classroom

respectively. Then, the progression for numbers that stood at $20.8 \%$ as against $4.2 \%$ in the control group. Thus the null hypothesis was rejected while the alternative was retained. This implies that visual discrimination training has a positive effect on reading among struggling readers. This knowledge will lead to improvement in pedagogic practices in primary schools. The study therefore recommends that visual discrimination training be introduced as earlier as possible, and reinforced in all classes in primary schools to give all children the possibility to improve.
\end{abstract} records and a standard oral reading test. The 24 most severe cases were subjected to ballot to distribute them into two groups (experimental and control). Each group had 12 participants including boys and girls between the ages of $10-11$ years. The pre-testpost-test techniques were used to measure the progress made by each group within a period of 8 weeks. Only the experimental group received the treatment exercise. The instruments used for data collection were a master sheet for reading assessment, test score sheet produce by the researcher, an interview guide for pupils and their teachers. Data were analysed using the statistical package SPSS 21.0. They were analyzed and presented descriptively using frequencies, percentages, tables and charts, while hypotheses were tested using the Chi-Square test of equality of proportions comparing the aggregated scores of the experimental and control group. Interviews were analysed using the thematic and case approach, and summarized in codegrounding-quotation tables and conceptual diagram. Results revealed that, there was a significant positive progression in the experimental group. Letters and words recognition stood at the $27.1 \%$ as against $6.2 \%$

KEY WORDS: Assessment, Visual, Discrimination, Training, Recognition, Letters, Reading, Struggling, Readers, Primary, School, Buea, Municipality

\section{INTRODUCTION}

Reading is an important component of the school curriculum, which determines the extent to which learners achieve academic competence and develop a positive self-esteem. It is a left brain activity which is often difficult to the right brain dominant learner.

Visual discrimination training is an intervention technique used in teaching to enable struggling readers recognises similarities and differences in print. Struggling readers are unable to read their notes and other age appropriate literature. This affects their academic achievement with negative consequences on their families the educational system and the larger community. Primary five pupils ought to read to cope with the workload in public examination the following year. Children in any given classroom come from different backgrounds with varied strengths, weaknesses and aspirations based on their exposure 
and hereditary factors. Some before schooling have been exposed to books with reading models at home .Others receive assistance with their school work from home teachers, parents and siblings who reinforce what was taught in school. While others who come from poor and underprivileged background, including hereditary factors rely solely on the school to provide them with the necessary support to enable them to read. Literature reveals that some struggling readers could be very intelligent but experience difficulties with reading requiring remedial instruction to be able to read. Teachers through training ought to understand their pupils, their characteristics, their socio cultural environment and the nature of reading to be able to help children with disabilities (struggling readers) in their classrooms and schools. They ought to be able to identify learners by their strengths and weaknesses and then focus on their strength to help them develop skills and eventually their full potentials for a healthy personality. Several efforts have been made by the educational system to adjust pedagogy practices to bridge the gap between proficient and struggling readers in Cameroon yet some children graduate or drop out from school without being able to read. My assumption is that more struggling readers will be able to read by primary five if provided with early and appropriate differentiated instruction. The purpose of this study is to investigate if visual discrimination training on the recognition of items has any effect on reading among struggling readers in primary five in the Buea municipality in Cameroon.

\section{Statement of the Problem}

This study was out to investigate the effect of visual discrimination on reading among struggling readers in primary five. Field observation reveals that struggling readers in primary five are often excluded in the learning to read process because their reading attempts were fraught with frequent stops and starts, with errors of omission, substitution, reversals and repetition. Struggling readers are often labelled as dull, stupid, lazy, slow learners and good for nothing children, though they may be very intelligent but experience difficulties with reading. This has negative consequences on the learners their family the educational family and the larger community. The few pupils who could read are often asked to read without any effort to motivate struggling readers to read. The classroom environment on their part is often not literacy friendly to help motivate those from poor and underprivileged home background to have materials to read.
Several literatures exist in Cameroon stating the different methods that could be used in teaching children how to read yet some children keep struggling with reading. To the best of my knowledge, no literature exists in Cameroon on how to assess struggling readers to determine why they struggle with reading before providing the remedial instructions. This study may give direction to the quality of instruction that is required to help struggling readers read. It is against this backdrop that this study sought to investigate the effect of visual discrimination training on reading among struggling readers in primary five.

\section{Objective of the Study}

To assess the effect of visual discrimination training in the recognition of letters on reading among struggling readers in primary school in Buea municipality Cameroon.

\section{Research Questions}

What is the effect of visual discrimination training in the recognition of letters on reading among struggling readers in primary five?

\section{Research Hypothesis}

Ho1: There is no impact on reading due to visual discrimination training in the recognition of letters and among struggling readers in primary five.

Ha1: There is an impact on reading due to visual discrimination training in the recognition of letters among struggling readers in primary five

\section{CONCEPTUAL} AND

THEORETICAL

\section{BACKGROUND}

Visual discrimination is the ability to recognise the similarities and differences in print. According to Hundt (2013), it is a tracking process, which is associated with how the eyes transmit visual impulses or information to the brain. To Gangwer (2010), it is the ability to perceive words accurately, noticing likenesses and differences in words, letters, numbers and other objects. He argues that visual discrimination deficit will cause the learner to experience reversals, omissions, additions and repetition when exposed to a reading task. He reiterates that children are often labelled as dull, stupid and lazy children, and also excluded in the learning to read process though they may be very intelligent but experience difficulties in reading. Arky (2014) argues that visual discrimination deficit affects the learners' academic, emotional and 
life skills. He stresses that academically, such children may have great difficulties with reading, writing and mathematics which cause them to develop low selfesteem and depression. This implies that there is the need to help struggling readers develop and acquire reading skills so that they can improve upon their reading performance, their academic achievement and develop a healthy personality.

Struggling readers are a category of learners who are unable to read age appropriate literature. They interpret what appears on print differently from what it actually is. This makes the reading experience painful and stressful for them due to frequent errors. According to Gambrel and Pressley (2003), struggling readers experience a series of other difficulties like imitating and completing tasks, working accurately, maintaining attention, remaining on the seat and following written and oral direction. This causes them to be unable to read and understand academic tasks, which leads to the development of low self-esteem. They emphasize that teachers ought to help such children in their classroom by including them in the reading experiences so that they can overcome this weakness if they must succeed in school. To Marling and Paugh (2004), struggling readers are pupils for whom reading is extremely difficult. They stress that many of them are labelled without any special reading assistance to help them read. They argue that such children depend on the teacher's instruction in the classroom to be able to read. This implies that teachers ought to be able to identify struggling readers in their classrooms and then assess them to identify why they struggle with reading. This will enable the teachers to provide them with the appropriate instruction that suit their specific needs.

Reading is a gradual process which develops from home to school based on background experience that the learner takes to school. It could be impaired by a number of factors requiring early intervention to enable the children improve upon their reading skills and develop a healthy personality. There is therefore the need to motivate, reinforce and expose them to practical activities to enable them to read and achieve academic success. According to Burns, Roe and Ross (1996), the ability to read enables one to function effectively in any society and to enjoy life in its fullness. Also, they stress that it is necessary for teachers to show pupils that being able to read is rewarding because it increases school success, helps in coping with everyday situations out of school and provides recreation. Besides, they argue that children, who do not understand the importance of reading will not be motivated to read, while those who can read will be motivated to read. Hoss (2004), hold that children who can read can be engaged in a world of knowledge to achieve academic success and end up with better jobs in the society. According to the National Institute for Child Health and Human Development (2007) the ability to read helps the child to build a high level of self-esteem and also eases learning transition from learning to read to reading to learn. They argue that the consequences of not being able to read places a road block for the individual in enjoying life in its fullness. In addition, they reiterate that, reading becomes a painful and stressful experience for poor readers as they frequently make errors. More so, they stress that this causes them to develop low self-esteem, as they grow ashamed struggling with what their classmates seem to read with ease. Besides, they emphasize that poor reading prevents the learner from reading to learn to learning to read, which keeps them from exploring a wealth of information that comes in print. Furthermore, they contend that such readers easily dropout of school due to frustration from not being able to cope with the demands of schooling. In addition, they argue that due to frustration, some get involved in crimes, drug abuse and alcohol to seek solace. They reiterate that in the world today, children who cannot read will not be able to access the wealth of knowledge available in print. This implies that there is need for educational stakeholders to pay greater attention to struggling readers, to enable them read over time. This will help them to avoid the consequences that may arise later in life due to the child's inability to read.

According to Yuh (2014) regular teachers can play a crucial role in reducing discrimination in school by including all children in the teaching and learning process. This view is shared by Nwazuoke(2000) that the classroom teacher is a significant person in the life of the children to help them succeed in school. He argues that if the teacher does not have sufficient professional training, it becomes difficult for them to be able to help the children to learn. According to Garnett (2010):

"Classroom conditions can affect a number of children like those from poor homes, those with attention deficit, those with learning disabilities who are the most vulnerable for not learning due to classroom experience. He argues that such learners 
may see the classroom as so crowded, busy, timedriven, spotlight for public attention as shame, private for teachers who tend to identify them based on their behaviour, activities focused whole group instruction, progress monitored and more which can affect their learning."

This implies that teachers ought to create a conducive classroom environment to help all children irrespective of their status. According to Nunam (2003), the acquisition of reading skills requires that, the learner master the basic language rules of phonology, morphology, syntax comprehension. To achieve success, the teacher must have a basic knowledge of strategies and skills to assist the learner acquire skills in reading. According to Torgessen, Houston, Rissman and Kosanavich (2007), reading teachers must work with small groups of learners who have different instructional needs to reach their individual needs. This implies that struggling readers ought to be provided with the necessary attention during lessons in small identified groups so as to be able to meet their specific learning needs rather than allowing them to wallow in misery during the regular reading sessions.

Stein and Walsh (1950), in their magnocellular deficit theory of dyslexia contest that struggling readers have a deficiency in their magnocellular zone of the brain, which causes them to read with errors. This view is supported by Snowling (2001), who states that struggling readers experience a decreased ability to detect fine motion which affects the way they perceive visual information. Also, they reiterate that such instability resulting to poor reading requires repeated instructions in order for the learner to eventually read. This implies that struggling readers experience reading difficulties beyond their control. This is the reason why must be provided with the necessary support to enable them to read over time.

Vygotsky (1920), in his theory of social constructivism holds that learning takes place in a zone in the brain referred to as "the zone of proximal development" with a lower and upper limit. He stresses that within the lower limit of this zone, children are capable of learning independently, information that is needed for survival within their environment. They stress that the learning of concepts, principles and skills to develop competence occurs within the upper limit of the brain, which requires that a more skilled person mentor the less skilled one through scaffolding. Tchombe, (2011), in articulating Vygotsky (1920), shares that when children learn through social interaction, they construct knowledge at two levels. Through practical activities and by interacting with others using speech and cultural tools to connect the meaning of their interpersonal world with others. This implies that teachers ought to provide struggling readers withthe opportunity to interact in the classroom independently and with the teachers and their peers.

According to Erikson (1950), in his theory of psychosocial development, human development unfolds in stages characterized by crisis. He argues that it is necessary to strike a balance during interaction for the individual to live a healthy and enjoyable life. He argues that children within the age bracket (6-13) move to the primary school with energy towards mastery of knowledge and intellectual skills due to their expansive imagination. Struggling readers in primary five (9-11) fall within this age bracket. He argues that failure to meet their specific learning needs can be dangerous because it can lead them to develop a sense of inferiority, unproductiveness and incompetence. This implies that labelling and excluding struggling readers in primary 5 is very dangerous for the personality of a growing child.

Gagne (2007) holds that children find learning to read difficult because they lack specific skills necessary for proficient reading. He argues that to help them to be able to read, there is a need to identify where their specific deficiency exists. He stresses that struggling readers should be assessed and be provided with the appropriate instruction so that they too can read. He argues that this will help them to develop a positive self-esteem and to become productive and competent to compete with their peers within and outside Cameroon. This view is supported by Burns et al (1996), that when struggling readers are motivated to begin reading a letter, two letter words and then three letter words that they see all the time, these words soon become sight words that they will eventually be able to recognise at a glance. In addition, they stress that this will encourage them to feel they too can read. Besides, they argue that, in this way, children will be motivated to persevere and learn more words that are complicated because they believe they can read.

This implies that struggling readers ought not to be excluded in the learning to read process because it has 
psychological and emotional effects on their behaviour with negative consequences that affect them. This neglectful attitude breeds crimes, revolts, emotionally unable people and mediocracy. Pupils will not be nurtured to persevere on any given tasks, which will be reflected in their later life characterised by negligence, laziness and inefficiency at work all of which lead to corruption. In this way, the school will fail to nurture in the learners the spirit of determination, endurance and hard work to become problem solvers rather than shying away from the problems and creating more problems for the individual and the society. How then, do we expect to automatically change to meet the goals of "vision $2035 "$ of producing inventors and entrepreneurs when we lack the persevering attitude to find solutions to existing problems in our classroom? With the attitude of excluding, the included, primary schools in Cameroon only help to increase the cost of Basic Education for the country. This is because teachers are being paid yearly to teach the same set of children in a particular class due to class repetition. In addition, some parents pay extra classes for their children to help them catch - up with their peers.

McREL(2013)contends that to help change school so that they can achieve their goals, data driven decisionmaking, leadership, manageable changes, shared leadership and continuous improvement focused on learners must be sought. He argues that it is necessary to focus on the learners' strength rather than their weaknesses and to understand how they can be motivated to achieve success. According to Tambo (2003), Cameroon's educational system experiences educational wastage when some pupils drop out of school because they cannot cope or because they experience constant repetition of classes. This is supported by the World Bank report (2014), on a study of the quality of Basic Education in Cameroon, which revealed that in 2010, during the National Early Grade Assessment (EGRA) $49 \%$ of $3^{\text {rd }}$ grade pupils had great difficulties in reading while $27 \%$ could not read at all. This implies that cumulatively, about $76 \%$ of primary school pupils in Cameroon experience difficulties with reading. This has negative consequences on the learner, their families, the educational system and the community at large.

Thus, it is necessary to seek for means to change attitude and level of commitment of teachers and the parents of struggling readers so that struggling readers in our primary schools can read and succeed in school for a better Cameroon tomorrow. In articulating the importance of this problem UNESCO (2008), reports that repetition, failure and school dropout rate of developing countries including Cameroon is a serious preoccupation with the following statistics; repetition $37.6 \%$,failure rate $40.0 \%$ and dropout rate $39.9 \%$ in primary schools. They contend that to reduce educational wastage especially failure and repetition rate, the Cameroon government implemented a pilot project to provide remediation instruction, which did not continue to fruition. According to Howerd (2003), to achieve educational goals it is necessary to adapt to cultural relevant curriculum, taking into consideration the rich and varied cultural wealth, knowledge and skills that diverse learners bring to school. He reiterates that such pedagogy empowers pupils intellectually, socially, emotionally and politically by using cultural referents to impact knowledge, skills and attitudes (p.382). Besides, he argues that in this way, the deficit based beliefs that some teachers have about their pupils will be rejected. Furthermore, he stresses that teaching should be dedicated to nurturing pupils' academic, socially, emotionally, culturally, and psychologically and their physiological wellbeing. Thus, it is necessary to improve upon the reading situation in Primary schools in Cameroon in order to meet up with the goals of "Vision 2035" of producing entrepreneurs and inventors in Cameroon. According to Smith and Tyler (2010), there is the need for early intervention for all struggling learners in the hope of preventing learning problems in the future. This is supported by Dion et al (2014); Ehriet al (2001); Fuchs et al (2004), as in Tyler (2010) that pupils who fail to acquire core skills in reading soon after entering school become poor readers who will not be able to cope on their own except provided with intensive and explicit instruction on the core reading skills. Many factors can be responsible for the reading difficulties experienced by struggling reader. These include auditory discrimination, phonological disorders, orthographic disorders, developmental disorders and visual discrimination just to name a few. Unless the exact cause of the reading difficulty is known, it will not be possible to present the appropriate instruction to suit the needs of the learner. This study is out to investigate the effect of visual discrimination training on reading among struggling readers in primary schools in Buea municipality and to make recommendations based on findings. 
Characteristics of Struggling Readers

Struggling readers are those pupils who are unable to read age appropriate literature. Such children are found in almost every classroom in Cameroon. This is a worry to parents and teachers because the situation affects their academic achievement. They are often labelled as dull, lazy, stupid and good for nothing children since their reading attempts are below that of their age appropriate peers. However, research findings reveal that IQ achievement discrepancy is not necessary in identifying struggling readers since it has very little in relationship between learning to read and intelligence level. (National Institute for Child Health and Development)

To O.T. Mom Learning (2009), struggling readers show symptoms of struggling with reading depending on the type of delay and can vary greatly from child to child. They may struggle to copy words, draw, in their quality of writing avoid puzzles, reverse and invert letters or words when reading, struggle to remember sight words or see similarities and differences in letters words, numbers, geometric shapes pictures and other objects.

According to Snowling (2001) Struggling readers are those whose reading ability is below that of their aged appropriate peers. They find reading the most arduous and frustrating activity to face since their difficulties are sometimes more than their desire to read. To (Hagis,1989) as in Burns, Roe and Ross(1996) struggling readers are often labelled as disabled, remedial, retarded, impaired, at risk, underachievers, non-proficient readers or struggling readers. They argue that such readers have behavioural and emotional problems. Beck (1988) as in Burns et al (1996) who hold that struggling readers have difficulties initiating and completing tasks, working accurately, maintaining attention, remaining on the seat and following oral or written direction. And that they may also have emotional issues like low selfconcept, poor frustration tolerance, and negative attitude which can make them unable to concentrate or unwilling to attempt learning tasks (Burns et al, 1996).

According to Frith (1997) as cited in Snowling (2001), such readers experience difficulties at the level of phonological representation which comes with a range of symptoms as seen in their behaviour. This is supported by Snowling (2001), that struggling readers experience problems of verbal short-term memory, non-word repetition deficit, poor phonological learning of new verbal information, word retrieval and rapid naming problems. In the same light Hulme and Snowling (1992) Swan and Goswami, (1997)Snowling (2000) as in Snowling (2001), hold that struggling readers come to reading tasks with poor specified phonological representations. This implies that the way in which the brain codes phonological representation is less efficient than that of the normally developing children despite the relative strength in semantics. Struggling readers have a reduced ability to detect flickers (Evans et al 1994) as in Snowling (2001). And that they often have reduced ability to detect coarse details but a normal ability to detect fine details (Livingstone et al 1990) as in Snowling (2001). They stress that there tend to be a prolonged persistence of visual images causing masking of vision on successive fixation (Slaughuis and Ryan (1999) as in Snowling (2001). They argue that struggling readers experience a decreased ability to detect fine motion (Cornelissen et al (1995) According to Steinet al (2000)as in Snowling(2001) the main visual difference between the proficient and struggling readers is in the magno function. They emphasize that struggling readers experience difficulties in the way they see images, and that experience letter blurredness and movement are due to the damage of the magnocellular components specialized in fast temporal movement.

To Ryan (2004) struggling readers often suffer a frustration that is centred around their inability to meet expectations. They emphasize that this frustrates their teachers and parents who value them as bright and enthusiastic children capable of learning to read and write, and they are eventually labelled as dull, lazy and stupid children. They argue that when this happens, the children suffer the pain of failing to meet the expectations of parents and teachers which cause them to develop a perfectionist expectation in order to deal with their anxiety. This causes them to grow up believing that it is terrible to make mistakes. Due to this status, struggling readers make many mistakes leading them to feel chronologically inadequate.

To Sabornie and Kauffman (1986), as in Heward(2003), struggling readers enjoy socially rewarding experiences in inclusive classrooms. They emphasize that this will depend on the social climate created by teachers, peers parents and others with whom students with disabilities interact. This implies that struggling readers in primary five have 
difficulties beyond their control. They need to be encouraged and motivated through instructional practices and attitudes that will encourage them to read.

According to Gagne (2007), struggling readers lack specific skills necessary for proficient reading. He stresses that to help them to be able to read, there is a need to identify where their specific deficiencies exist. He argues that, an informal evaluation can help to determine information to help fill possible gaps in reading skills. He reiterates that this will help the teacher to target instruction to directly help the learner to develop the necessary skills in reading. She stresses that struggling readers vary greatly in the specific skills they lack. For example:

"Poor phonemic awareness, unable to blend smoothly, improper directional tracking, gaps in directing knowledge of complete phonemes, not processing print phonologically, not paying attention to details, difficulties with complex codes, gaps in advanced skills, difficulty handling multisyllabic words, Poor comprehension, limited vocabulary and lack of fluency."

This implies that struggling readers in primary five have difficulties beyond their control. It is therefore necessary for parents and teachers to understand why some children struggle with reading. This will enable them to be able to motivate struggling readers through instructional practices, enriching environment for literacy and attitude change, so that they too can develop skills in reading.

\section{Why Some Children Struggle with reading}

Struggling to read is a situation whereby a learner is unable to read fluently age appropriate literature. Several studies have been carried out to unveil reasons why some children keep struggling with reading. According to Reading Rocket (2011), reading difficulties are related to inherited brain difficulties and that this can be corrected with appropriate early instruction. Also, they identified three main areas that struggling readers have deficit as follows; phonological awareness, rapid naming and word retrieval and holding sounds in working memory. Besides, they argue that at the level of phonological awareness, struggling readers are unable to segment words into sounds and to manipulate the sounds of the words in different ways because they do not know that letters represent sounds. Furthermore, they contend that struggling readers are unable to map speech into print, which affects their ability to develop beginning reading skills. More so, they stress that they do not understand the alphabetic principles, which cause them to be able to develop decoding and encoding skills needed for spelling. This causes them to rely on their knowledge of memorized words as "sight words" which guide their reading of new words. In addition, they emphasize that struggling readers are unable to recognise common spelling patterns in words and as a result, they fail to benefit from the regularities that exist in English language (word pattern). This also helps to affect their reading comprehension.

Besides (NICHD 2013), holds that struggling readers have difficulties with rapid naming and word retrieval. In addition, they argue that this is responsible for their slowness in identifying letters, numbers, words, colours and so on. Furthermore, they stress that they have difficulties learning letter names, their sounds and the regular high frequency words. Also, they emphasize that struggling readers learn information and forget it later, which requires that, learning names of items, must be repeated over a long period so that they can achieve success. They contest that struggling readers often make errors of reversals $|b|$ for $\backslash d \backslash$ and also say letters backwards (top) for (pot). Furthermore, they stress that they need to decode same words over and over before they can recognise them quickly and automatically. This makes reading for them slow and laborious and as a result they hate and avoid reading.

More so, they argue that struggling readers also have difficulties holding information in their short term memory while the information is being processed. Besides, they stress that they are unable to recall a string of numbers, letters, words or repeated unfamiliar words accurately which affects their ability to segment and blend sounds. This implies that struggling readers are unable to recognise similarities in letters, words, numbers, geometric shapes and pictures, which is responsible for their slowness in reading.

To Kelly and Campbell (2012), there are several causes why some children keep struggling with reading which include the absence of reading role models and life experiences, the acquisition of reading skills, visual processing disorders and learning disabilities. Also, they emphasize that struggling 
readers are unable to recognise sight words at appropriate speed which limits their comprehension. Besides, they argue that struggling readers are unable to transfer knowledge which requires the ability to recognise similarities and differences in letters and words. More so, they contend that struggling readers face difficulties processing and memorizing information due to their slow processing power.

Martin and Pappas (2006), as cited in Kelly and Campbell (2012), opine that due to the difficulties that struggling readers experience with reading they have resulted to self-doubt and low self-esteem believing that they can never be able to read in life. According to American Psychological Association (2016) reading research has proven that reading difficulties are often caused by specific brain based differences on how children process information. They argue that effective instruction can improve how pupils with dyslexia read and spell. This implies that struggling readers have a range of difficulties that affect their ability to read but with effective instruction, they can improve with time. It is therefore necessary to identify the exact cause of the reading difficulties to be able to provide the appropriate instruction that will suit the needs of the specific learner.

\section{Ideas about Reading}

Reading is an important skill for learners, in the learning process, which determines the extent to which success is achieved in school. According to Anderson (2003), readers combine information from the text and their own background knowledge to build meaning in a fluent process. Also, he stresses that learners need to master this process in order to succeed in school. To Hoss (2004), the ability to read allows one to interpret and become engaged in the world of knowledge. Also, he stresses that the acquisition of reading skills helps learners to access and use information that helps them to improve upon their knowledge by accessing information from different sources. Besides, he emphasizes that such learners become lifelong readers since they use the fluency decoding and vocabulary they have developed to understand written materials and read from a wide variety of sources. More so, he argues that reading skills help learners to discover more about the world and use the knowledge to improve their levels.

According to the Duane (2000), as cited by Hoss (2014), many children living in poverty lack the skills that will allow them to become lifelong readers. In addition, he stresses that such children may not be able to read signs, understand medical information or prescription, directions or apply for jobs that require basic reading test. He emphasizes that successful readers build background knowledge about many different subjects that they can use later.

This view is supported by Lake, and Perry(2000), that reading is the cornerstone to success and that children who have not had reading fundamentals taught or do not have good word decoding skills will start having problems because the subject matter becomes a little more difficult beyond their ability to decode words. They argue that when this happens they begin to hate reading.

The National Institute for Child Health and Human Development (NICHD ,2007), holds that reading skills help the child to build a high level of selfesteem and also make learning transition from learning to read to reading to learn. Also, they stress that the consequences of being a poor reader places a road block for the individual in enjoying life in its fullness. Besides, they argue that reading becomes a painful experience for poor readers as they frequently stop and start, mispronounce some words and skip others. In addition, they develop a low self-esteem as they grow ashamed struggling with a skill their classmates seems to master with ease. Furthermore, they contest that poor reading prevents readers from reading to learn to learning to read which keeps them from exploring science history, literature in themes and a wealth of other literature that is presented in print. Also, they emphasize that poor readers easily drop out of school due to frustration from not being able to cope with the demands of academics. NICHD(2007) stresses that such children easily get involved in crimes due to frustration or get involved in drugs and alcohol to seek for solace. They stress that in the world today, children who cannot read will not be able to access the wealth of knowledge available in print, thus, the need to identify why they cannot read and help them out with reading skills. To Burns, Roe, and Ross 1996), learning to read is an important experience in the child's life which does not happen automatically from birth. It takes a gradual process that builds up from an early age as a child acquires new understanding about reading and writing as means of communication. Also, they argue that the ability to read helps children to acquire knowledge and information which helps them in achieving academic success. According to Reading Rocket 
(2011), it is necessary for teachers and parents to have basic ideas about what it takes for a child to learn how to read, how each child can be taught how to read and how to motivate the child to read. They stress that, it is also necessary for them to know why some children struggle with reading. In addition, they stress that this knowledge will help them to better appreciate the importance of reading, know how to motivate children to read, plan reading instructions and use the appropriate strategies and instructional materials to achieve success.

According to the Reading Report card NAEP (2009), in America fourth grade students read below grade level. This is in line with the results of the reading assessment in primary school in Cameroon conducted by Word bank (2010), which reveals that about $76 \%$ of primary school pupils in Cameroon are struggling with reading. This view is supported by Reading Rocket (2011) that learners come from varied backgrounds with varied experiences that they bring into the school. Besides they argue that teachers are supposed to know this in order to be able to nurture reading competence in the learners. More so, they stress that while some children acquire reading skills with ease because of their early exposure to reading and print, others struggle with reading because of lack of background experience from home. Furthermore, they contend that those who had been exposed to reading materials at home read easier than those who have never been read to. They argue that such children will face chronic difficulties in the classroom and that teachers must be ready to meet the challenges they face.

In addition they reiterate that teachers and parents should know that learning to read is a complex process that draws upon many skills that need to be developed at the same time including letter identification, letter blend, and strategies to easily identify and read words. Besides, they commend that it is necessary for teachers to teach with the aim of balancing the various components of reading (phonemic awareness, phonics, fluency, vocabulary, and comprehension) in their teaching while fostering love of books, words and stories. They stress that teachers like parents should know that children who struggle with reading usually have problems with sounding words (the alphabetic principle).This will enable them to employ strategies that will ease their understanding and reading and to know that sounds are linked to certain letters and letter pattern.
Also, they stress that teachers and parents should know that what happens before school matters a lot. This is strongly related to how easy it is to learn how to read in first grade. Besides, they argue that if a child is able to recognise and name letters of the alphabet, understand the sequential order of the alphabet, where to begin reading and the direction to follow, understand the sounds in the words, reading becomes easier for them. More so, they emphasize that learning to read is closely tied to talking and listening to young children because these help them with skills they need for reading. Furthermore, they reiterate that parents should provide children with the right words to use during conversation and that without help struggling readers will continue to struggle with reading but with help they can succeed. They argue that teaching children how to read is a team effort that begins from the home to school and continues as the child progresses in grade.

According to Garnett (2010), classroom conditions can affect a number of children. He argues that children from poor homes, those with attention deficit, those with learning disabilities are amongst the most vulnerable for not learning due to classroom experiences. Besides, he contests that such children may find the classroom so crowded, busy, timedriven, spotlight for public attention as shame, private for teachers who tend to identify them based on their behaviour, activities focused, whole group instruction, progress monitored and more which can affect their learning. Also, he stresses that teachers should bear this in mind and plan the classroom environment in a way that will provide more support and motivation rather than distraction. This will help all the children to learn in an inclusive classroom.

This implies that improving classroom environment with materials that promote interaction and reading will help struggling readers to learn to read faster and regularly. This will provide opportunity for children from poor homes where they cannot provide them with reading materials to learn how to read, read frequently and to nurture the reading culture in all the learners irrespective of their home backgrounds.

Thus, the acquisition of reading skills is very necessary in the life of every individual. This will enable them get more information about the world in which we are living and be able to solve real life problems by learning from others through reading. 


\section{Instructing Reading in Inclusive Classrooms}

Learners in every given classroom in the primary school are unique in terms of their intellectual and physical abilities. Struggling readers are pupils who cannot read age appropriate literature. They may find classroom reading assignment stressful and challenging to cope with. This affects their academic achievement and the development of low- selfesteem. Such pupils require remedial instruction to enable them match up with their peers and to cope with their academic challenges. Gambrel and Pressley (2003) lament that due to the complex nature of the classroom, time factor and the expertise that some children will require the class teachers can hardly meet up with the reading needs of struggling readers. They stress that struggling readers should be provided with an expert teacher to handle their individual learner needs. In articulating this view, Snow (1998) as cited in Gambrel and Pressley (2003), suggests that the best defense against failure to read fluently is an excellent instruction from and exemplary teacher. He argues that reading teachers should themselves possess the reading skills to teach others how to read.

To Pearson(1996), as in Gambrel and Pressley (2003), that teachers must be able to understand how to teach reading so that they can adapt their learning environment, instructional materials and teaching strategies to suit the particular needs of the learner and the particular environment. This implies that teaching struggling readers to be able to read fluently requires expertise knowledge by the teacher to be able to choose the appropriate content, strategies and instructional materials that can motivate the learners, and also provide them the opportunity to practice. This is supported by (Adams and Henry,1997), as in Gambrel and Pressley (2003) who intimate that children need to be provided with the opportunity to sound out words even if this means they have to struggle. They stress that many children struggling with reading do not know how to begin to sound out words since they have a limited knowledge of the alphabetic principle. They argue that these type of learners are limited to being able to sound out only beginning letters of words.

Burns, Roe and Ross (1996), opine that the goal of reading instruction is to turn all the words that pupils need to recognise in print into sight words so that the child can acquire speed and comprehension while reading. They stress that when children are familiar with the words on print, it enhances their speed and comprehension over time. They recommend that teachers should use teaching strategies and instructional materials that will develop visual discrimination in the learners. And that this will help them to achieve success in helping the children read. They argue that for children to read they must first acquire knowledge of letter sound combination. This they stress can be achieved when they are exposed to learn letter names early so that both teacher and pupils have a common understanding when the teacher refers to a particular letter(Farr and Roser,1979) Also, they emphasize that this will help them to be able to decode words correctly.(Hafner and Jolly,1982), as in Laurice (2000), stress that children who learn both the names and letters of alphabet can read better than children who learn only letter names. In the same light Adams (1990) Pearson (1993) (Stanovich,1993/1994: Yopp,1992) as in Laurice (2000), opine that successful reading requires the understanding that speech consisting of a sense of unit sounds which helps to increase one's knowledge of the language. To buttress this point, Pearson (1993), as cited in Laurice (2000) holds that when children are encouraged to invent spellings of words, they become conscious of some of the sounds that make up the words. He argues that when children are exposed to literature that plays the sounds and also get involved in games that draw their attention to the sounds of the language they learn to read better. (Griffith and Olson, 1992, Yopp, 19992) as in Laurice, (2000).

To Wagner (2015), games and participatory activities are very useful to reinforce the fundamental skills that a child needs to be able to read. Also, he argues that at the elementary level children should be allowed to ride bikes, play games, with letters and words, do puzzles involving seeing the differences, reading games like hopscotch, reading words in blocks to check speed, bingo games just to name a few. Besides he reiterates such activities will help improve the visual discrimination skills and reading fluency of struggling readers. According to Burns et al(1996), sight word recognition will help children read more rapidly and fluently because such words are easily recognised without having to resort to analysis. They argue that comprehension and speed greatly suffers if a reader has to pause too often to analyse unfamiliar words. Also, they stress that many words in English language are not spelled the way they sound. Thus, children need to recognise them on sight word as a whole configuration to ease reading. More so, they stress that when sight words are easily recognised it 
encourages a positive attitude towards reading. Furthermore, they reiterate that, this gives the children the chance to engage in successful reading experiences. Besides they emphasize that presenting children with sight words help them to associate reading with meaning rather than meaningless memorizations. Also, they recommend that teachers should teach common irregularly spelled words like(come, to, night ) and frequently used regularly spelled words like (in, it, is, if, an, and) that children can read connected sentences early in the programme. Furthermore, they emphasize that teachers should teach words with regular spellings patterns like came, fame, same/can, pan, fan etc. This will help the children to easily read by substituting the initial sounds of the word thereby improving their visual discrimination skills.

In addition, they emphasize that before children learn sight words, they must have developed visual discrimination skills to see differences and similarities amongst printed words. More so, they argue that it is necessary for children to know the names of the letters of alphabet to facilitate discussion of likeness and differences amongst words. Furthermore, they emphasize that teachers should identify sight word for pupils, pronounce them, pair them with pictures and draw the children's attention to the words so that when next they see them they will recognise them. They stress that children should be encouraged to pay attention to details of words through questioning of letter combination, position of letter to aid retention. Besides, they stress that similar words should be paired and pupils' attention drawn to the position of the words to help pupils identify them when next they see them. This implies that sight words should be identified in all subject areas to help pupils read with ease and comprehension.

Burns et al (1996), opines that reading instruction could also be improved by using instructional materials that can enhance sight word recognition. They stress that children acquire sight words without analysing them when they frequently see them. Thus teachers can expose pupils to sight word recognition by using instructional material like word card, number cards, letter cards sentence card, word wall just to name a few. Besides, they could prepare short reading passages with repetitive sequence of words to motivate the children to want to read because some of the words are already familiar to them. This will give even children from poor home where their parents cannot provide them with readers an opportunity to read.

The pupils have the opportunity to practise reading while interacting with their peers. Besides, they should get the children involved in classroom activities and games that will motivate them to recognise sight words and also be able to read. According to Allington and McGillFranzen,(1996);Lyon and Moats (1997);Sack(1999), as cited in Gagne(2007), children who find learning to read and write difficult are best served by designing and delivering sufficient and appropriate instruction and opportunity to practice. He stresses that children have reading difficulties because they lack specific skills necessary for proficient reading. And that to help them to be able to read there is a need to identify where their specific deficiency exist. He argues that an informal evaluation can help to determine information to help determine possible gaps in necessary reading skills. Stresses that this will help the teacher to target instruction to directly help the learner to develop skills in reading. She stresses that struggling readers vary greatly in specific skills like poor phonemic awareness, smooth blending, improper directional tracking, poor phonological processing, paying attention to details, difficulties with complex codes, difficulty handling multisyllabic words and many others.

This implies that there is the need to assess the reading ability of struggling readers in order to identify where there is a deficiency so as to be able to plan for the appropriate remediation lessons. Burns, et al(1996)opine that teachers can help children build background experience in reading by trying to meet their specific needs with available resources. They stress that this can be achieved by reading to the children daily whether planned or unplanned to introduce them to new vocabulary, language pattern, concepts cultures and life styles. This will help the children develop interest in reading and the desire to read to learn. More so, they reiterate that children could be exposed to sight word recognition by posting word cards on the walls of the classroom, bearing names of objects, people, numbers and colours to help pupils acquire sight words instantly without analysing them. They argue that the word wall has many advantages as follows;

$>$ It serves as a quick reference for the right spelling of words. 
$>$ Children learn to recognise words by reading them often.

$>$ They learn the alphabetical sequencing in the course of placing their words

$>$ It eases dictionary reading for the children in the future.

Also, they emphasize that teachers could also expose the children to passages with repeated sequence of words. This will motivate the children to want to read because some of the words will already be familiar. They stress that after a model reading or two by the teacher and pointing to the respective words the teacher will realize that the children will be eager to read.

Furthermore, they reiterate that when teachers ask children to donate words then write them out on papers and give the children each to keep and learn how to spell and pronounce the word; this will help the children to learn how to read faster. Such words will soon become sight words for the learner to motivate and encourage the children to develop interest in reading because they believe they can read. Teachers should therefore focus on improving sight word recognition to help pupils recognise familiar words. This can be achieved by improving the classroom environment with word cards, letter cards, word wall, and sentence cards, to provide the pupils with the opportunity to practice reading while interacting with their peers. Besides, they should get the children involved in classroom activities and games that will motivate them to recognise sight words and also be able to read them.

According to Kelly and Campbell(2012)reading instruction for struggling readers requires that teachers' instructional programme should be focused on these essential components; That is,

$>$ explicit phonemic instruction

$>$ Listening comprehension

$>$ Reading comprehension

$>$ Tutoring on one to one

$>$ Extending reading from the classroom to the home.

They emphasize that though there are many reading programme used in schools, none of them is a "cure all". They argue that it is not just the method that matters but the teacher. They stress that teacher's knowledge of reading, continuous professional development and skills are essential to implement any programme that focus on helping struggling readers. Also, they reiterate that struggling readers will make more progress if they are taught by committed and informed teachers (Kelly and Campbell, 2012).

This implies that instructing struggling readers is a complex experience that requires careful planning and systematic implementation to achieve success. Such teachers must themselves be able to read, know how to assess the struggling readers to identify why they struggle with reading and then to plan an appropriate remedial lesson using the appropriate materials. This will help them meet the needs of the struggling readers in their schools. This implies that, teaching strategies, instructional materials, and classroom environment could be used to help struggling readers to acquire reading skills..

However, the practice in primary school in Cameroon is that even when reading difficulties are identified, teachers will hardly create time to tackle them because they are more concerned with syllabus coverage rather than to provide remedial lessons for the development of skills and competence. This frustrates the children the more especially when they are pushed to higher levels due to the policy of mass promotion without remediation lessons to ensure that they have acquired the necessary skills. This only helps to widen the gap between proficient and nonproficient readers in Primary schools in Cameroon.

To narrow the gap between proficient readers and struggling readers, the classroom teachers must make an effort to vary their teaching strategies. They could use locally produced instructional materials that could be made available in all schools irrespective of where the schools are located to help the children develop interest in reading .In this way the locally made reading materials will be displaced in the classroom from time to time for all children to read. Such words will soon become sight word that children will easily recognize when they are expected to read because they frequently see the word around their classroom environment. This motivates the children to become interested in reading because they believe they can read.

\section{The Magnocellular Deficit Theory of Dyslexia by Stein and Walsh (1997)}

This theory postulates that the magnocellular dysfunction is responsible for all poor directing of visual stimuli through the eyes to the brain. Stein and 
Walsh(1997) stress that a deficiency in the magnosystem affects the way that information is received and transmitted to the brain. In addition, they argue that, it is the presence of this deficit that creates reading difficulties for struggling readers. Besides, they reiterate that this difficulty is not only restricted to the visual path way but also could be generalized to all modalities, including visual, auditory as well as tactile stimulus. More so, they contend when the specialized cells found in the magnocellular system are affected, this creates reading difficulties for the learner. Furthermore, they reiterate that, the neural pathway sub-serves in different functions, which in hibits impulses in the parvo-system. While the eyes are moving to enable the viewer, perceive a stationary image even though the eyes are in constant movement (Stein and Walsh 1997).

This view supports Lovegrove and Slaghuis (1986) as cited in Skottum(2000), that the magnocellular system suppresses the parvocellular system at saccades and that when this happens, it causes the activities in the parvocellular system to terminate, to prevent the activities during fixation from lingering into the next fixation. They argue that the absence of each fixation will cause confusion in the brain, which leads to reading difficulties.

To Shillcock and Scott (2015), there are two cells responsible for vision in the natural pathway. The magnocells (large) and the parvocells (small) cells, which control vision. They stress that any deficit in them will result to reading difficulties. Sceniak, Chatterjee, and Callaway (2006), contest that, this part of the brain containing the visual pathway leading to the primary visual nucleus (LGN) relates to three types of cells. The upper layer of cells known as the parvocellular neurons and the magnocellular neurons responsible for colour vision and processing fine spatial details, which are found throughout the (LGN) with higher conclusion velocity. They stress that the focus of the magnocellular theory is on the "magnocellular neurons" which responds to low spatial resolutions and high temporal frequencies caused by the movement. They argue that the cells in the retina may selectively project to the parvocellular or magnocellular neurons and will results to abnormalities, which can cause interruption of neuronal migration to disrupt the magnocellular system. They argue that when such disruption or suppression occurs in the parvocellular system, it causes the parvocellular system to terminate to prevent activity elicited during one fixation from lingering into that from the next fixation. He argues that without this suppression, the parvocellular activity from different fixations would be confused. He stresses that this suppression effect is absent or diminished in dyslexic, which is the cause of the inability to keep separate neural activity elicited during different fixations. This deficit creates reading difficulties causing struggling readers to interpret what their eyes see differently from what it actually is (Skottun, 2000).

To buttress this point, Stein, (2003), opines that visual magnocellular system results to binocular and visual perception instability due to a reduced ability to detect rapidly changing visual stimuli as the eyes scan through print, that such difficulty can result to visual stress and sensory interrogation problem where letters appear blur or move when trying to read. He argues that when this happens, it creates difficulties in determining the order of letters in words and results to lack of reading fluency.

In the same light, Stein and Walsh (2001) and Stein (2008) contend that the magnocells is in deep layers of visual thalami nucleus (Lateral GeniculaleNulceus) in struggling readers or dyslexics were disordered and overall smaller than in their normal size. Moreover, that impairment in the magnocellular system could be due to genetic factors or deficiency in Omega 3 and Omega 6 since the magnocells depends on the fatty acid for survival to maintain stability in membrane surrounding the brain in order to function effectively. However, Brain (2003), holds that there is hope for struggling readers if given the appropriate intervention. This view was supported by American Psychological Association (2016) that new advances in brain injury are helping scientists to discover what happens in the brain when children read and what happens before and after systematic research based reading instruction. This helps to confirm that the right teaching methods can normalise brain function and thereby improve the child's reading skills since dyslexia does not affect vision or lower intelligence. This implies that though struggling readers in primary 5 experience difficulties in reading, beyond their control due to the deficiency in their magno system of their brains, they too can read with time if they are provided with the right instruction. Struggling readers have trouble with reading because they are unable to transmit visual stimuli at the appropriate rate, which affects the rate of fixation of the parvo system causing 
them to read with errors. Like all other children in the classroom requiring special needs education, struggling readers must be given the opportunity to learn by providing them with the appropriate remediation instruction. This will help them to develop a positive self -esteem, to avoid future learning problems and to live a better life.

Struggling readers have the right to education like their peers who are proficient readers. They must be given the opportunity to learn. Erikson (1950) in his classification of human development holds that children at primary level should be handled with love and empathy since it is a delicate period of their life when they develop competences. This will lead to the development of a healthy personality. Therefore, struggling readers ought to be provided with the appropriate instruction that will suit their need. This will help them to be able to interact fully in the society and to become productive complement and live a happy and fulfilled life.

The theoretical implication of this theory is that, a deficiency in the magnocellur system of the brain will cause reading difficulties for the reader. This implies that struggling readers experience reading difficulties because they have a deficiency in their magnocelluler system of the brain, which cause them to interpret visual information differently from what they really are. Evans et al (1994), as cited by Snowling (2001), argue that struggling readers often have reduced ability to detect coarse details Also; they experience prolonged persistence of visual images causing masking of vision on successive fixation. To buttress this point Cornelissen, Hansen, Gilchrist, Cormack, Essex and Frankish (1998) as cited in Snowling (2001) contest that struggling readers experience a decrease ability to detect fine motion which affects the way they perceive visual information. Thus, it is necessary to assess struggling readers to ascertain their reading difficulties so as to be able to plan the appropriate remediation lessons that will help them develop reading skills (Snowling, 2001).

The practical implication of this theory is that since the deficit at the magno-system cause visual information to be perceived differently due to poor fixation, there is need to assess struggling readers to be certain of the appropriate remediation instruction that will suit the needs of the learner. According to Gagne (2007) it is necessary to identify why some children struggle with reading through informal assessment so that the teacher can provide them with the appropriate remediation instruction to help them develop skills in reading supports this.

However, the practical experience in the field is that struggling readers are often ridiculed, neglected and labelled because of their inability to read. They are hardly involved in the reading experience rather; those who are proficient in reading are given more opportunity to practice leaving the struggling readers to wallow in their misery. Besides, the classroom environments do not nurture in them the reading culture The walls of the classroom are usually bear without word cards nor sentence cards that could be used to reinforce lessons taught, motivate the learners to read and also reinforce the participatory approach to teaching and learning. This implies that if pupils are to learn in class irrespective of their status, teachers ought to change their attitude to involve them in learning through hands on activates.

\section{The Social Constructivist Theory by Lev Vygotsky} (1920)

Vygotsky is a Russian psychologist who believes that interaction is a powerful tool for development. He stresses that when a child interacts with culture that is expressed through social interaction and language, this provides motivation for development. Besides, both intellectual and socio-cognitive development requires social interaction, social demands and social stimulation for development to take place (Vygotsky 1920). He argues that, there is a difference between what a child can learn on his or her own and what they can achieve when they receive help from a more skilled person. He contends that learning occurs in a zone known as the zone of proximal development having an upper and lower limit. He stresses that at the lower limit the child is able to learn independently basic knowledge that will permit him or her to survive in the environment. He emphasizes that, to learn concepts, principles and more complex information, which occurs within the upper limit of the zone of proximal development, children need help from a more skilled person who must mentor them through scaffolding. He refers to scaffolding as a process of instruction where a more skilled person reduces the amount of support provided to the less skilled person as the learner begins to master the skills being taught (Vygotsky 1978).

Driscoll (1994) supports the view, and Hausfather, (1996), as cited in Tchombe (2011), that human 
beings use tools that develop from culture like speech and writing to mediate their social environment. They stress that children develop these tools just to function socially but will need to internalize them to develop high thinking skills. They argue that to achieve success in teaching, children's instruction should be designed to reach a developmental level that is just above the pupils' current development level. They argue that for effective scaffolding it is necessary for partners to be at different developmental levels with the higher-level partner being aware of this principle. They emphasize that, scaffolding and reciprocal teaching are effective strategies that could be used to access the zone of proximal development. They reiterate that this requires that the teacher provide pupils with opportunity to extend their current skills and knowledge. They stress that success can be achieved when teachers engage pupils' interest, simplify tasks so that they can manage and motivate pupils to pursue the instructional goals. They contend that, teachers should look at discrepancies between student's effort and the solution by controlling frustration and risk and then modelling an idealized vision of the act. They emphasize that reciprocal teach in grand dialogue should be used where teachers and pupils discuss to help go beyond only answering questions but also learning to discuss.

Tchombe (2011), in articulating how children learn through social interaction opines that children construct knowledge through social interaction at two levels. She stresses that children construct knowledge through practical activities at interpersonal level and through interacting with others using speech and cultural tools to connect the meaning of their interpersonal world with others.

In the same light, Psychohawks (2010), holds that children's thinking is affected by their knowledge of social community which is learnt from either culture or psychological cultural tools referred to as language. They argue that intelligence is "the capacity to learn from instruction" which emphasizes the need for a more knowledgeable person to teach the less knowledgeable. They stress that there is a gap between what the child knows and what the child is capable of learning (the zone of proximal development).More so, that through the guidance of a more knowledgeable other, the child can potentially gain knowledge that is already in him/her. They emphasize that such knowledge should be appropriate for the child's level of comprehension. They stress that nothing that is not at their zone of proximal development can be learnt. They argue that once the child attains his or her potential shift, the child can continue learning more complex materials (Vygotsky 1997).

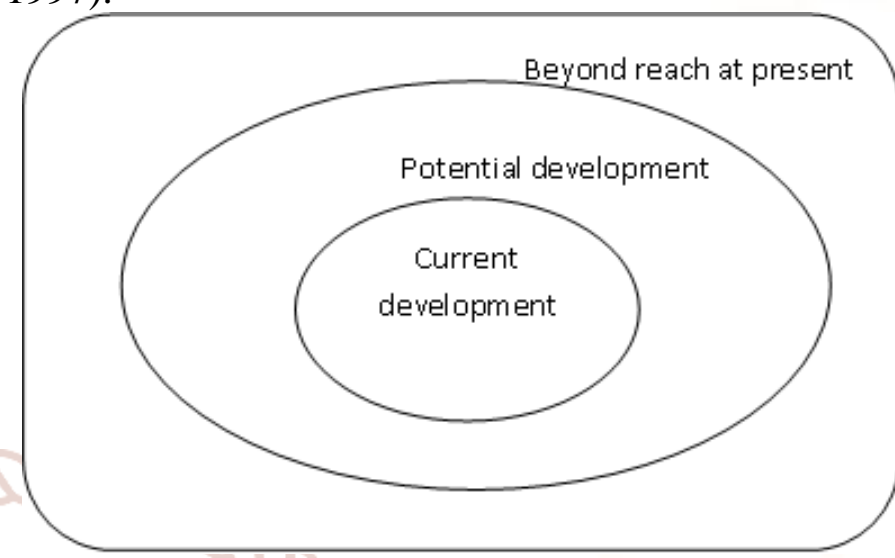

Figure 1: Diagram to Demonstrate ZPD Source: Psychohawks (2010)

To buttress this point, Hurst (2013), opines that Vygotsky was more concerned with the constructing of the best possible theory on the transfer of knowledge. More so, he identified the zone of proximal development as a zone where learning and teaching occurs. They argue that this zone has two levels and that level one is concerned with what the child can do without help while level two is what the child can do with help from a more skilled person. They reiterate that for success to be achieved, it must go through the process of scaffolding in which the amount of support that is provided is gradually withheld as the learner progresses and eventually does the activity without support so that it can be permanent.

The theoretical implication of this theory is that when adults interact with children, they show the meaning they attach to objects, events and experiences. This is because thought and language begin as a social activity, which gradually become stools for thinking. It also implies that children can perform as persons that are more skilled and become competent individuals. It stresses that success will depend on observation and assessment to determine the child's actual potential in order to know what new potentials could be added. Besides, it implies that there is a gap between what the child knows and what he/she is capable of knowing. However, when the child attains the potentials, a shift occurs and the child can continue learning materials that are more complex. 
The practical implication is that the child's environment should be enriched with materials that will foster interaction between the child and other adults. This will enable the adult to observe and identify potential areas of difficulties and gradually guide the child through scaffolding to acquire the necessary skills in life. This will help the children to be able to acquire basic knowledge, concepts and principles that will guide them to continue to learn more complex and higher-level materials.

However, the practical experience in the field is that struggling readers are often not treated as individuals. They are treated as a class not minding whether they can acquire the new skills based on what they know. They are forced to read more complex materials, which frustrates them more because the gap between what they know and what they are expected to know is too wide. This causes some of them to shy away from reading experiences with the feeling that they cannot read. To make the situation worst, teachers hardly give them the opportunity to participate in the reading lessons with their peers at any given opportunity by providing them with an enriched literacy classroom environment. Their classrooms are usually bare which do not provide them / with experience to improve their skills, rather they are neglected to wallow in their misery, but quick to label them as dull, stupid, slow learners, and lazy pupils. The teaching methods used are hardly interactive to permit the children learn from peers or the teacher. Besides, the classroom environments are hardly convenient for peer tutoring because they lack letter cards, word cards, number cards or sentence cards that can help these children learn how to read with their more skilled peers serving as their instructors. This implies that there is need for an interactive teaching strategy where teachers will serve as facilitators to guide children to learn.

\section{METHODOLOGY}

The research design used for this study is the experimental design. Specifically the quasiexperimental type of double group pre-test and posttests sub-type. The experimental group was consist of four participants per school who were taught for eight weeks using the participatory approach. This approach was adopted because it enabled the researcher to work with the participants in a natural classroom environment in various actives using item cards, and taking part in practical exercises and assignments. The control group was consist of four participants per school who did not receive any intervention but continued their normal session with their class teacher. The quasi-experimental design was seen as the appropriate design because the study sought to establish the relationship that exist between the dependent and independent variable

According to Amin (2005), experimental research allows the researcher to study variables that could not ethically be manipulated by the experimenter. In this light, the researcher was able to conduct interviews with the participants and their teachers. Shuttle worth (2008),Fraenkel and Wallen (2006), and Cohen, Monion and Morrison(2007) contend that in quasiexperimental design participants are not allocated at random, but selected judgemental. This permitted the researcher together with the class teacher to nominate struggling readers in their respective classrooms. Participants were sampled through multiple stage sampling to ensure that they met the criterion for selection. They argue that quasi-experimental studies operate in a natural setting, which permits the extraneous variables that could affect the results to be controlled to reduce threads to internal validity. In this light, the researcher imposed a criterion for selection requiring that the participants must be in class must be struggling readers, must be aged 9-11 years and could be male or female.

The nominees were subjected through an oral reading test to ascertain if they were struggling readers before subjecting them to a pre-test. This was at the commencement of the experiment and a post-test after the treatment exercise that was administers only to the experimental group. This was so to enable the researcher to be able to make inferences at the end of the experiment. Both groups were tested at the same time, at the beginning of the experiment (pre-test) and at the end of the treatment period (post-test) using the same instrument and by the researcher. They were followed- up over the same duration before the post evaluation. Data were collected directly from the participants for 10 weeks from the $18^{\text {th }}$ of April to the $5^{\text {th }}$ of June 2015. One week was for the selection period that included teachers' nomination, examination of class records and the standard test. The intervention period covered 8 weeks from the pre-test to the post test. The pupils and the teachers were interviewed as to have more information on the challenges they face with respect to reading over the remaining one week. 
This study was carried out in Buea municipality in Fako Division of the South West Region of Cameroon. It is one of the sub-divisions within Fako division. This is a cosmopolitan town located at the foot of Mount Fako with 156 primary schools dispersed in the municipality. It harbours a population with varied cultural and socioeconomic background. The people are involved in all works of life. The settlement areas are carved in a triangular form accessed by road. According to (Nana, 2015; Shadish, Cook and Campbell 2000; Trochim, 2006) experimental study did not permit asimple random sampling of participants throughout the study. It requires a well-demarcated geographical area purposively selected based on the nature of the study. In line with this view, three schools with three different background were selected purposefully within Buea municipality. That is, Government school Bonduma group1, C. B. C. Bolifamba mile and Bonandive academic centre Woniamavio. These schools were widely dispersed to ensure that children from different background were included in the study.

This study is focused on struggling readers in primary five in Buea municipality. According to Fraenkel and Wallen (2007), the population of interest in a study is a group of people who possess certain characteristics. The target population for this study was all primary five pupils who are struggling with reading. These schools included all government schools, all mission schools and all lay private schools within Buea municipality, while the accessible population was the three schools from where the sample was drawn. That is, Government school Bunduma group1, Cameroon Baptist Convention Bolifamba mile 16 and Bonandive Academic centre Woniamavio. They were chosen through the simple random sampling method based on their categoryso as to give all the schools an equal opportunity to participate in the study.

Table 1: Summary statistics for primary schools on enrolment sex and class 2014/2015.

\begin{tabular}{|c|c|c|c|c|c|c|c|c|c|c|c|c|c|c|c|c|c|c|c|c|c|c|}
\hline SN & $\begin{array}{c}\text { School } \\
\text { types }\end{array}$ & $\begin{array}{c}\text { Class } \\
1 \\
\end{array}$ & \begin{tabular}{|c|} 
Class \\
2 \\
\end{tabular} & $\begin{array}{c}\text { Class } \\
3 \\
\end{array}$ & \begin{tabular}{|c|} 
Class \\
4 \\
\end{tabular} & $\begin{array}{c}\text { Class } \\
5 \\
\end{array}$ & \begin{tabular}{|c|} 
Class \\
6 \\
\end{tabular} & t & & & & & & & & & & & & & & \\
\hline 1 & $\begin{array}{c}\text { Governme } \\
\mathrm{nt}\end{array}$ & 325 & 319 & 644 & 303 & 338 & 641 & 359 & 363 & 723 & 433 & 403 & 846 & 522 & 426 & 9552 & 383 & 351 & 734 & $\begin{array}{c}236 \\
0 \\
\end{array}$ & 2200 & $\begin{array}{c}1314 \\
0\end{array}$ \\
\hline 2 & Catholic & 202 & 197 & 399 & 219 & 246 & 465 & 251 & 252 & 503 & 274 & 264 & 538 & 293 & 314 & 6077 & 249 & 276 & 525 & $\begin{array}{c}151 \\
5\end{array}$ & 1549 & 8507 \\
\hline 3 & Baptist & 49 & 47 & 96 & 49 & 37 & 86 & 54 & 43 & 97 & 54 & 46 & 100 & 60 & 47 & 1077 & 55 & 44 & 99 & 309 & 264 & 1555 \\
\hline 4 & $\begin{array}{c}\text { Presbyteria } \\
\mathrm{n}\end{array}$ & 62 & 43 & 105 & 62 & 74 & 136 & 51 & 77 & 128 & 47 & 56 & 103 & 77 & 79 & 1566 & 49 & 69 & 118 & 360 & 398 & 2156 \\
\hline 5 & $\begin{array}{l}\text { Anglo } \\
\text { Arabic }\end{array}$ & 6 & 9 & & 6 & 7 & 13 & 4 & 5 & 9 & 4 & 6 & 10 & 6 & 5 & 111 & 5 & 2 & 7 & 32 & 34 & 165 \\
\hline 6 & Lay private & 944 & 894 & 1881 & 840 & 924 & 1754 & 833 & 900 & $\begin{array}{c}173 \\
3\end{array}$ & 808 & 806 & $\begin{array}{c}161 \\
7\end{array}$ & 740 & 752 & $\begin{array}{c}1480 \\
0\end{array}$ & 674 & 605 & $\begin{array}{c}127 \\
9\end{array}$ & $\begin{array}{c}492 \\
3\end{array}$ & 4881 & $\begin{array}{c}2306 \\
4\end{array}$ \\
\hline $\begin{array}{c}\text { Tota } \\
1 \\
\end{array}$ & 1588 & 1509 & 3140 & 1479 & 1626 & 3095 & 1552 & 1640 & $\begin{array}{c}319 \\
3\end{array}$ & $\begin{array}{c}162 \\
0\end{array}$ & \begin{tabular}{c|}
158 \\
1
\end{tabular} & $\begin{array}{c}321 \\
4\end{array}$ & \begin{tabular}{|c|}
169 \\
8
\end{tabular} & $\begin{array}{c}162 \\
3 \\
\end{array}$ & $\begin{array}{c}3318 \\
3\end{array}$ & 1415 & \begin{tabular}{|c|}
134 \\
7 \\
\end{tabular} & \begin{tabular}{|c|}
276 \\
2 \\
\end{tabular} & $\begin{array}{c}949 \\
9 \\
\end{array}$ & $\begin{array}{c}932 \\
6 \\
\end{array}$ & \begin{tabular}{|c|}
4858 \\
7 \\
\end{tabular} & \\
\hline
\end{tabular}

Source: Inspectorate of Basic education-Buea.

The non-probability sampling method was used to select the sample. This is a method where some elements of the population have no chance of being selected. The samples were selected based on the assumption that they will provide the necessary data for the study. Fraenkel and Wallen (2006) and Cohen, Moion and Morrison (2007)

Table 2: Sample Size

\begin{tabular}{|c|c|c|c|c|c|c|}
\hline \multirow{2}{*}{ Category of School } & \multirow{2}{*}{ Class } & \multirow{2}{*}{$\begin{array}{l}\text { No in } \\
\text { Class }\end{array}$} & \multirow{2}{*}{$\begin{array}{l}\text { Number of } \\
\text { struggling readers }\end{array}$} & \multicolumn{3}{|c|}{ Number sampled } \\
\hline & & & & Control & Experimental & Total \\
\hline $\begin{array}{c}\text { Government } \\
\text { G.S. Bonduma } 1\end{array}$ & 5 & 26 & $16(61.5 \%)$ & 4 & 4 & 8 \\
\hline $\begin{array}{c}\text { Mission } \\
\text { C.B.C. mile } 16\end{array}$ & 5 & 18 & $14(77.8 \%)$ & 4 & 4 & 8 \\
\hline $\begin{array}{c}\text { Lay private } \\
\text { Bonandive Academic Centre }\end{array}$ & 5 & 17 & $10(58.8 \%)$ & 4 & 4 & 8 \\
\hline Total & & 61 & 40 & 12 & 12 & 24 \\
\hline
\end{tabular}


The sample size for this study was 24 participants (18 boys and 6 girls) drawn from three primary schools (government, mission, and private) within Buea municipality. Eight pupils participated from each school. The criterion for participation was that the pupils from each school must be in class five, must be aged between 9- 11 years, must be a struggling reader and could be male or female. Out of the 61 struggling readers in the three schools, 24 of them were sampled. Class 5 was chosen because it is the last but one class in the primary school where pupils are expected to have acquired visual discrimination skills to enable them read age appropriate literature before graduation.

According to Picciano (1996), a sample size can be determined by using sampling theories or determined by the nature of the research. Also he stresses that experimental studies could tolerate a minimal samples sizes for statistical significance to be valued and that even a school could be chosen for such studies. To buttress this point Gall and Borg (2015) states that causal comparative and experimental research methodology can tolerate a sample size of fewer than 15 participants in each group because it is out to establish the relationship that exist between the variables.

The selection of schools was done considering the nature of the study which sought to establish the relationship between variable and also following the stratified simple random sampling method. According to McMillan(1996) and Cohen, Monion and Morrison (2007) there is no precise way of generalising judgmental or convenient sample of the population considering that such studies sought to establish the relationship that exist between variable They stress that such studies could be carried out even in a single school and the results indicate the relationship. They argue that once the relation has been determined spending longer periods in the field will be a waste of time. They recommend that if there is need for generalisation same study could be carried out in different geographical areas. Three schools were selected through stratified simple random sampling whereby within each category of school was represented.

Participants were selected purposively through a multi-stage screening. The first stage consisted of teacher nomination, the second stage the examination of their class records and the third stage through a standard test. During this phase, all the nominee were subjected to an oral reading test to ascertain that they were struggling readers using Gray's Oral Reading Test (GORT-5) (Patino; 2014). This test was out to measure reading fluency and comprehension. Participants were given a short passage to read to and answer questions from the passage. The researcher to suit the level of the learners constructed the short passage. She adopted the scoring scale from Gray's oral reading test(GORT-5 (Patinon2014).The researcher observed and followed along as each participant read. She took note on the errors, fluency, and comprehension of the passage. For each correct word the child, scored (.5) mark while comprehension was scored ( 2 marks). The grading wasdone on a scale of 20.Then; the last eight participants with the least score in each school were taken for the study.

"Dig a hole and feed the pig. He left for school and did not get to the pig. His father saw him and was happy. But did not know that he left the pig without food".

\section{Question}

What is the passage about?

Table 3: Score sheet for oral reading Test (GORT-5)

\begin{tabular}{|c|c|c|c|}
\hline SN & G.P.S. BondumaGroup 1 -16 & C.B.C.BolifambaMile 16 - 14 & BonandiveAcademic Centre-10 \\
\hline 1 & 14.5 & 13.5 & 13.5 \\
\hline 2 & 14 & 12.5 & 13 \\
\hline 3 & 14 & 12.5 & 13 \\
\hline & 13.5 & 12 & 12.5 \\
\hline & 13.5 & 12 & 12.5 \\
\hline 4 & 13 & 12 & 12.5 \\
\hline 5 & 13 & 11.5 & 12 \\
\hline 6 & 12.5 & 11 & 11.5 \\
\hline 7 & 12 & 11 & 11 \\
\hline 8 & 11 & 11 & 10 \\
\hline
\end{tabular}


International Journal of Trend in Scientific Research and Development (IJTSRD) ISSN: 2456-6470

\begin{tabular}{|c|c|c|c|}
\hline 9 & 10 & 10 & 19 \\
\hline 10 & 10 & 9 & 8 \\
\hline 11 & 9 & 8 & \\
\hline 12 & 8 & 8 & \\
\hline 13 & 7 & 7 & \\
\hline 14 & 6 & 6 & \\
\hline 15 & 6 & & \\
\hline 16 & 5 & & \\
\hline
\end{tabular}

The Participant were later divided into the controlled and experimental group at random. This process is diagrammatically represented on the sample flow chart below as in Nana (2015).

Number of pupils evaluated: 61

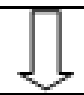

Number of pupils identified as struggling readers through teachers' nomination: $\mathbf{4 4}$

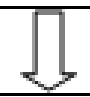

Number of struggling readers identified through school records: $\mathbf{4 5}$

\}

Number of struggling readers identified through teachers' nomination and school records: 44

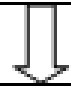

Number of struggling readers identified through the standard test: $\mathbf{4 0}$

$\prod$

Number included in the study based on degree of severity and the designed sample size: $\mathbf{2 4}$

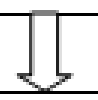

Number of children validated for analysis following exploratory statistics: $\mathbf{2 4}$

Figure 3: Summary of the Identification Process

Data triangulation was employed in the study. This involved collecting data qualitatively through interviews, and quantitatively through test scores. The following instruments were used:

$>$ A master sheet for reading assessment for pre-test, post-test.

$>$ Test score sheets from researcher-made test that enabled the researcher to monitor the progress made by the participant in the experimental group.

$>$ Interview guide for pupils also enabled the researcher to collect more information from the participants on the difficulties that struggling readers' experiences with reading and how they affects their personality development.
$>$ Interview guide for teachers enabled the researcher to collect information from the class teacher as to whether they are able to recognize struggling readers in their classroom and how they meet their needs.

The master plan activity sheet was structured into two phases. Section A: was focused on demographic data to enable the researcher collect some personal information about the individual pupil, while section B: focused on instruction and section C: focused on knowledge items. It contained 20 items directed towards testing the pupils' visual discrimination skills on letters, words, numbers, geometric shapes and 
picture images. Items 1-4 focused on testing the participants' visual discrimination skills with respect to recognition of capital letters, small letters, easily confusing letters and their similarities and differences. Items 5-9 focused on testing the pupils' visual discrimination skills of words, spelt with same letters at different positions, identification of specified words with similar endings, and the similarities and differences of specified words. Items 9-12 focused on testing the participants' visual discrimination skills for numbers. Pupils were tested on identifying single digit numbers, double digit numbers, place value of specified numbers and similarities and differences of specified numbers. Items13-16 was focused on testing pupils' visual discrimination skills for geometric shapes. Pupils were tested on their ability to identify specified shapes, their similarities and differences, number of sides, and shapes within a specified shape. For items, 17-20 the focus was on testing participants' ability to visually discriminate among pictures provided. Pupils were tested on their ability to identify similar pictures, their similarities and differences, and also to identify the missing features in the pictures.

All the items were evaluated on a frequency count from 1-4 on a duration of 60 seconds. Each pupil was given up to 60 seconds (1minute) to respond to the item presented. If the child provided the right response within the period of one minute, he or she was graded as follows. Less than $25 \mathrm{sec}=1$ (very mild), less than $35 \mathrm{sec}=2$ (mild), less than $45 \mathrm{sec}=3$ (severe) less than $60 \mathrm{sec}=4$ (very severe). Items for which the wrong response was given or not given at all were scored 4 . This implies that the earlier the response given the higher the Childs' visual discrimination skills and the later the response provided the lesser the child visual discrimination skills. This was intended to help the researcher to observe if the pupils were having visual discrimination difficulties with letters, words, numbers, shapes and picture images before applying the treatment exercise. This guided the researcher to prepare an appropriate treatment exercise to improve the visual discrimination skills for struggling readers in primary five.

This instrument was adapted from the master sheet of reading assessment for primary schools in Nigeria, constructed by professor Ihenacho for the University of Jos Nigeria (1986). This was because it gives a general view on certain issues related to reading difficulties and ensured that the particular requirements for visual discrimination training on the recognition of items was fulfilled. The technique of frequency count was adopted while the other items were modified to suit the study, which was focused on visual discrimination training.

\section{Test score sheet}

The test score sheet for assessing the struggling readers during the treatment exercise was designed by the researcher. They were meant to assess if the treatment was achieving its objectives. The scores sheets were structured into contained knowledge items. The scores for each item were indicated against the items throughout the evaluation for each school. Test 1 had 8 items and was focused on testing pupils' ability to recognise similarities and differences in letters and words while test 2; had 12 items which dwelled on pupils' ability to recognise similarities and differences in numbers, geometric shapes and pictures. Pupils in each school were tested on the same instructions.

\section{Interview Guide for Pupils}

The interview guide for teachers was also structured into 3 sections as follows; Section A demographic data, section $B$ psychological data, Section C: knowledge items. The psychological items were 9 and they focused on finding out if pupils would like to learn how to read and how they felt when they were ridiculed because they could not read. They were also interviewed on the difficulties they faced with reading and who they expected to help them read. The assistance they needed from their parents, teachers and the school was also sought. Besides, they were interviewed on what the school could do to help struggling reads to be able to read and if they think their inability to read they affected their academic performance. More so, the researcher wanted to know if they were happy with the massive promotion that is practiced in school and why. While section $\mathrm{C}$ was focused on testing them orally if they could recognise the similarities and differences in letters, words, numbers, geometric shapes and pictures. (See appendix E). The purpose of this instrument was to get more information about the difficulties that some struggling readers face with reading and their feeling about their performance.

\section{Interview guide for teachers}

The interview guide for teachers was structured in 2 sections. Section A was focussed on demographic data while section $B$ was focused on pedagogic 
knowledge. The pedagogic section had 10 items, which focused on investigating whether the teachers could identify struggling readers in their classrooms and their opinion why some children struggle with reading. Their views were also sought on what the children can do to be able to read, what parents could do to help their children read and what the teachers could also do to help the struggling readers in their classrooms and schools to read. Besides, they were interviewed on what the school could do to enable struggling readers read, what strategies could be used to help struggling readers recognize letters, words, numbers, geometric shapes and pictures. Further more teachers were asked of the strategies that could be used to help children read and to nurture in them the reading culture. The interview guide for teachers constructed by the researcher was aimed at getting more information from the teacher about the struggling readers and their perception about their struggling condition in reading.

\section{Validity and Reliability of Instrument}

Validation of research instrument is very important to ensure that the instruments measure what they intended to measure. This was done in two phases.

\section{Content Validity}

To ensure the content validity, the research instruments were constructed and presented to a specialist in learning disabilities to ascertain whether the instruments suit the characteristics of the learners or not. Thereafter, the same instruments were presented to the supervisor for scrutiny. This led to some modification $n$ and adjustment of some items to ensure that the objectives of the study are attained.

\section{Face Validity \\ Pilot Test}

The researcher carried out a pilot test with four struggling readers in G.P.S Bonadikombo mile 4 Limbe that had the same characteristics with the participants and was not part of the sample population to check for any ambiguity in content. They were nominated by the class teacher and subjected to an oral reading test by the researcher. The purpose was to ascertain their status as struggling readers. They were later assign to the experimental and control group through simple random sampling. The researcher administered the test to the four participants. The class teacher taught those in the experimental group for two weeks using the scheme produced by the researcher for this study while those in the control group received no such treatment. After two weeks, the four participants were subjected to a second test. They were further exposed to a semi-structured interview to get more information about the difficulties they face with reading. No major discrepancy was observed and the teacher concluded that the test items were well understandable and within the level of the pupils.

\section{Reliability of the Instruments}

The test-retest reliability test was used in the study. The same test was administered (as pre-test and posttest) to the same set of respondents after intervention with the experimental group by the class teacher. Then, the results of the two tests were compared and analysed using Cronbach's alpha with the formula:

$$
: a=\frac{N \cdot \bar{C}}{\bar{V}+(N-1) \cdot \bar{C}}
$$

Where $\mathrm{N}=$ No. of items, $\bar{C}=$ Average inter item covariance

$\bar{V}=$ Average Variance, $\mathrm{a}=$ Cronbach alpha reliability

Note: the higher the item, the higher the alpha and the lower the item the lower the alpha

The progression was computed based on the differences in scores between the two tests. The evaluation was based on frequency count as follows: very mild-4; mild-3; servere-2; very servere-1; the four grading were later collapsed to two grading (mild and severe) to enable the researcher draw inferences as to whether the progression was positive or negative. That is, a participant with mild status at pretest and very mild at post-test for instance will be considered as having progressed just like one with very severe at post-test will be considered that he or she has not progressed. Meaning that the disability has not improved.

Cronbach Alpha reliability coefficient was big enough (Alpha=0.733) implying that responses were consistent in their trend. The internal consistency assumption therefore is not violated.

\section{Experimental Procedure}

After the selection of the schools, the researcher began with the experiment. She constructed a timetable to guide her schedules to the selected schools. When she got to each schools, she went straight to the head teachers office to obtain permission and to explain the purpose of her visit. She was later led to the classrooms were she informed the pupils and their teachers of the purpose of her visit. 
Then, the class teachers nominated the struggling readers in their respective classroom. All the norminee were subjected to multiple sampling (teacher nomination, observation of the progress record chart and Gray's oral reading test) those with the eight worst marks were chosen for the study while the rest were sent back to their classroom. All the eight participants were tested on the same day using the same instrument and scoring scale. This was to ensure that there was no sampling bias.

On such a situation, the researcher's time table was not strictly followed. She got to the school by $7: 30$ am and worked with individual pupil. Testing for each individual lasted for 20 minutes until all the eight participant in the school were tested. Teaching commenced with the next visit to the school following the researcher's time table. Only those in the experimental group received the intervention while those in the control group when back to class to continue with their normal classes. This intervention were guided by the scheme of work produced by the researcher. Teaching continued throughout the weeks for four weeks in all the school. After four weeks of teaching the first evaluation was given to check if the treatment exercise was having any positive effect on the development of visual discrimination skills for the participants. Individual scores were recorded while teaching continued. Four weeks later the second evaluation test was given and the scores recorded and compared with the previous individual scores to check for improvement. This was followed by revision and the administering of the post-test to the 24 participant following the principles observed during the pre-test. During the last week when the participants were already relaxed with the researcher, interviews were conducted to get more information on the difficulties that struggling readers face with reading and their feeling about their status as struggling readers. The interview in each school lasted for $1 \mathrm{hr} 20$ minutes considering that each participant had about 10 minutes. The class teachers were also interviewed on their perception about struggling readers and their pedagogic knowledge in handling them. This lasted for about 15 minutes with each teacher having 5 minutes.

In all, the researcher spent 10 weeks in the field visiting each school thrice a week to collect the data. A total of 25 hours 45 minutes were spent in the field as follows; Pre-test:2hours 40 minutes (20minutes each), post-test:2hours 40 minutes (20 minutes each), interview for pupils: $1 \mathrm{hr}$ hours (7miniutes each) interviews for teachers 15 minutes (5minutes each) and 17 hours 30 minutes for interaction and teaching with the experimental group. The mean scores of the two groups (experimental and control) were compared and inferences drawn, interpretation and discussion made based on the findings

\section{Method of Data Collection}

Data was collected qualitatively and quantitatively to minimise bias. After the identification of the participants, the 24 participants were subjected to a pre-test. This was followed by the administration of the treatment exercise only to the experimental group. During this period, those in the experimental group were tested twice to check if the treatment exercise was achieving its objectives. Thereafter, a post-test was administered to the 24 participants to find out if there was any improvement with the experimental group that received the treatment exercise. Later the participants and their teachers were subjected to interviews to get more information about their difficulties with reading and how the teachers handle this situation in school. A total of 25 hours 45 minutes were spent in the field Data was transcribed descriptively, inferentially and into themes to ease analysis and the drawing of inferences.

The organization of study indicators that led to the various variables under their respective hypothesis is summarized in the table on the operationalization of variables below.

\section{Data Processing and Analysis}

Data were entered using Epi Info 6.04d (CDC, 2001), after template was tested by statistician and candidate. Data were then exported to SPSS version 21.0 (IBM Inc., 2012). Descriptive analysis employed frequency, proportion and Multiple-Responses Analysis (MRA) as the variables were categorical.

Progression was computed based on the difference in score between two tests. The various levels of performance were given scores as follow: very mild $=4$; mild $=3$; severe $=2$; very severe $=1$. A participant with mild status at pre-test and very mild at post test for instance, was considered as having progressed, this was same with a participant with very severe at pre-test and severe at post-test. The differences between the experimental and control groups were carried out using Chi Square Test of Equality of Proportions. 
Interviews were analysed using the process of thematic analysis whereby concepts or ideas were grouped under umbrella terms or key words.

Results were summarized in tables, charts, conceptual diagrams and code-grounding-quotation tables. Statistics were discussed at the $95 \%$ CL scales.

\section{FINDINGS}

Four items were tested. They sought to find out if struggling readers trained to sort out vowel letters, capital letters, and middle case letters, to recognise the similarities and differences in letters can read letters correctly as presented in the table below in all the

\section{Pre-test for Experimental Group}

Ability to Work with Letter at Pre-Test: Experimental Group

\begin{tabular}{|c|c|c|c|c|c|c|c|}
\hline \multirow{2}{*}{$\begin{array}{c}\text { Ability to Work with Letter } \\
\text { Experimental Group }\end{array}$} & \multirow{2}{*}{$\begin{array}{l}\text { Very } \\
\text { Mild } \\
\end{array}$} & \multirow{2}{*}{ Mild } & \multirow{2}{*}{ Severe } & \multirow{2}{*}{$\begin{array}{l}\text { Very } \\
\text { Severe }\end{array}$} & \multicolumn{2}{|c|}{ Collapse } & \multirow{2}{*}{$\mathbf{N}$} \\
\hline & & & & & Mild & Sev & \\
\hline $\begin{array}{l}\text { ort out vowel let } \\
\text { the letter }\end{array}$ & $\begin{array}{c}3 \\
25.0 \%\end{array}$ & $\begin{array}{r}0 \\
\left(0.0^{c}\right.\end{array}$ & (8. & $\begin{array}{r}8 \\
(66.7\end{array}$ & $\begin{array}{r}3 \\
25.0\end{array}$ & $\begin{array}{r}9 \\
(75.0\end{array}$ & 12 \\
\hline $\mathrm{B}, \mathrm{b}, \mathrm{P}, \mathrm{g}, \mathrm{D}, \mathrm{M}$ & $\begin{array}{c}1 \\
(8.3 \%)\end{array}$ & $\begin{array}{r}3 \\
(25.0\end{array}$ & $\begin{array}{r}2 \\
(16.7\end{array}$ & $\begin{array}{r}6 \\
(50.0\end{array}$ & 4 & 66. & 12 \\
\hline Sort out small le & $\begin{array}{r}2 \\
(16.7 \%)\end{array}$ & $\begin{array}{r}1 \\
(8.3\end{array}$ & $\begin{array}{c}5 \\
(41.7 \%)\end{array}$ & $\begin{array}{r}4 \\
\left(33.3^{c}\right.\end{array}$ & $\begin{array}{r}3 \\
5.0\end{array}$ & $\begin{array}{r}9 \\
(75.0\end{array}$ & 12 \\
\hline $\begin{array}{r}\text { Bring out } t \\
\text { lifferences betw }\end{array}$ & $\begin{array}{c}3 \\
(25.0 \%) \\
\end{array}$ & $\begin{array}{c}0 \\
(0.0 \%)\end{array}$ & $\begin{array}{c}1 \\
(8.3 \%)\end{array}$ & $\begin{array}{c}8 \\
(66.7 \%) \\
\end{array}$ & $\begin{array}{r}3 \\
(25.0 \\
\end{array}$ & $\begin{array}{r}9 \\
(75.0 \\
\end{array}$ & 1 \\
\hline e Response Se & $\begin{array}{c}9 \\
(18.8 \%) \\
\end{array}$ & $\begin{array}{c}4 \\
(8.3 \%) \\
\end{array}$ & $\begin{array}{c}9 \\
(18.8 \%) \\
\end{array}$ & $\begin{array}{c}26 \\
(54.2 \%) \\
\end{array}$ & $\begin{array}{c}13 \\
(27.1 \%) \\
\end{array}$ & $\begin{array}{c}35 \\
(72.9 \%) \\
\end{array}$ & 4 \\
\hline
\end{tabular}

Very mild: $\leq 20 \mathrm{sec} ;$ Mild= 21-30 sec; Severe $=31-40 \mathrm{sec} ;$ Very severe $=41 \mathrm{sec}$ and above

The above table reveals that out of the 12 pupils tested for their ability to work with letters in the pre-test ,9 of them $(75 \%)$ had severe visual discrimination difficulties in sorting out letters amongst other letters $(66.8 \%)$ of them had severe difficulties while $4(66.7 \%)$ of them had mild difficulties.

Testing them on their ability to sort out small letters from other letters $9(75 \%)$ of them had difficulties to sort out small letters while $3(3 \%)$ of them had mild disabilities with sorting small letters.

Lastly, the pre-test for ability to bring out similarities and differences in letters showed that $9(75 \%)$ of them had usual discrimination difficulties to bring out the similarities and differences in letters while $3(25 \%)$ of them had mild difficulties. This implies that struggling readers in class 5 had visual discrimination difficulties with reading 4 letters.

\section{Ability to Work with Letter at Pre-Test: Control Group}

\begin{tabular}{|c|c|c|c|c|c|c|c|}
\hline & \multirow{2}{*}{$\begin{array}{l}\text { Very } \\
\text { mild }\end{array}$} & \multirow{2}{*}{ Mild } & \multirow{2}{*}{ Severe } & \multirow{2}{*}{$\begin{array}{l}\text { Very } \\
\text { severe }\end{array}$} & \multicolumn{2}{|c|}{ Collapse } & \\
\hline Control Group & & & & & Mild & Severe & \\
\hline $\begin{array}{l}\text { Sort out vowel let } \\
\text { the letter }\end{array}$ & $\begin{array}{c}5 \\
41.79\end{array}$ & $\begin{array}{c}1 \\
830\end{array}$ & 2 & $\begin{array}{c}4 \\
33.3 \%)\end{array}$ & $\begin{array}{c}6 \\
0.0 \%)\end{array}$ & $\begin{array}{r}6 \\
(50.0\end{array}$ & 12 \\
\hline $\begin{array}{r}\text { Sort out capital le } \\
\mathrm{f},\end{array}$ & $\begin{array}{c}3 \\
25.0 \%) \\
\end{array}$ & $\begin{array}{c}2 \\
(16.7 \%)\end{array}$ & $\begin{array}{r}2 \\
16.7 \\
\end{array}$ & $\begin{array}{c}5 \\
(41.7 \%) \\
\end{array}$ & $\begin{array}{c}5 \\
41.7 \%) \\
\end{array}$ & $\begin{array}{r}7 \\
(58.3 \\
\end{array}$ & \\
\hline $\begin{array}{r}\text { Sort out small le } \\
\mathrm{m}\end{array}$ & $\begin{array}{c}2 \\
16.7 \%) \\
\end{array}$ & $\begin{array}{c}1 \\
(8.3 \%)\end{array}$ & $\begin{array}{c}3 \\
25.0 \%) \\
\end{array}$ & $\begin{array}{c}6 \\
(50.0 \%) \\
\end{array}$ & $\begin{array}{c}3 \\
(25.0 \%) \\
\end{array}$ & $\begin{array}{c}9 \\
(75.0 \%) \\
\end{array}$ & 12 \\
\hline $\begin{array}{l}\text { Bring out the } \\
\text { lifferences betwee }\end{array}$ & $\begin{array}{c}2 \\
(16.7 \%)\end{array}$ & $\begin{array}{c}0 \\
(0.0 \%) \\
\end{array}$ & $\begin{array}{c}3 \\
(25.0 \%) \\
\end{array}$ & $\begin{array}{c}7 \\
(58.3 \%) \\
\end{array}$ & $\begin{array}{c}2 \\
(16.7 \%)\end{array}$ & $\begin{array}{c}10 \\
(83.3 \%)\end{array}$ & 12 \\
\hline $\mathrm{N}$ & $\begin{array}{c}12 \\
(25.0 \%)\end{array}$ & $\begin{array}{c}4 \\
(8.3 \%)\end{array}$ & $\begin{array}{c}10 \\
(20.8 \%)\end{array}$ & $\begin{array}{c}22 \\
(45.8 \%)\end{array}$ & $\begin{array}{c}16 \\
(33.3 \%)\end{array}$ & $\begin{array}{c}32 \\
(66.7 \%)\end{array}$ & 48 \\
\hline
\end{tabular}


The table above reveals that out of 12 pupils in the control group during the pre-test $6(50 \%)$ of them had mild visual discrimination difficulties with sorting out vowel letters from other letters. While 6(50\%) of them had difficulties regarding their ability to sort capital letters from other letters $5(41.7 \%)$ of them had mild visual discrimination abilities while $7(58.3 \%)$ had severe visual discrimination abilities.

Also, $9(75 \%)$ of them had severe visual discrimination abilities while $3(25 \%)$ of them had mild visual difficulties with sorting of small letters. Then, for the ability to discriminate between similarities and differences in letters, 10(83.3\%) had severe disabilities while $2(16.7 \%)$ of them had mild visual discrimination ability to bring out similarities and differences in letters. This implies that most of the struggling readers had severe difficulties with discriminating letters.

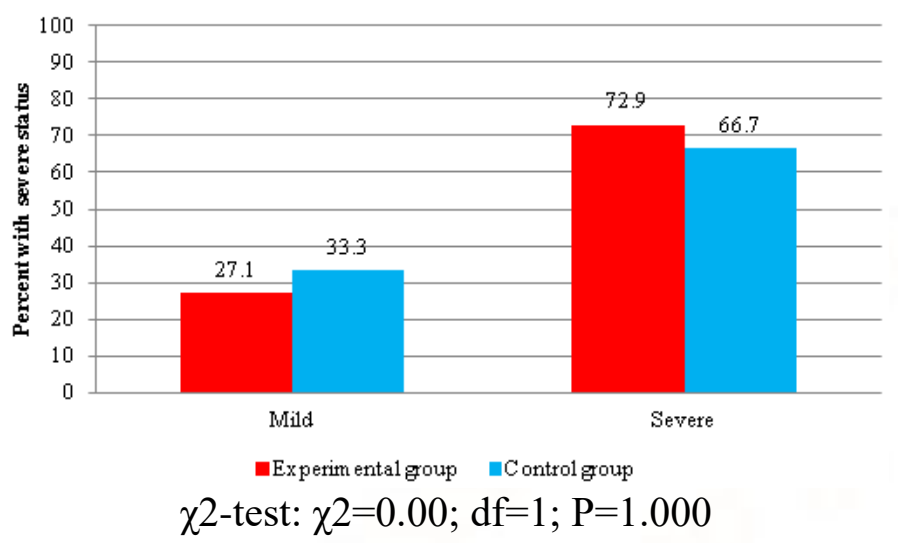

Comparing Children Status at Pre-Test between Control and Experimental Groups for Ability to Work with Letter

The initial status of the children indicates that in both the experimental and the control groups, the majority had severe disabilities with a proportion of $72.9 \%$ (MRS: $\left.\mathrm{n}_{\text {responses }}=35\right)$ and $66.7 \%\left(\right.$ MRS: $\left.\mathrm{n}_{\text {responses }}=32\right)$ for the experimental and control group respectively and the difference here was not significant $(\chi 2$-test: $\mathrm{P}>0.05)$, which is good for the validity of the data.

\section{Formative}

\section{Ability to Work with letter at Formative Evaluation: Experimental Group}

\begin{tabular}{|c|c|c|c|c|c|c|c|}
\hline \multirow{2}{*}{$\begin{array}{l}\text { Ability to work with Letters } \\
\text { Experimental Group }\end{array}$} & \multirow{2}{*}{$\begin{array}{l}\text { Very } \\
\text { Mild }\end{array}$} & \multirow{2}{*}{ Mild } & \multirow{2}{*}{ Severe } & \multirow{2}{*}{$\begin{array}{l}\text { Very } \\
\text { Severe }\end{array}$} & \multicolumn{2}{|c|}{ Collapse } & \multirow[b]{2}{*}{$\mathbf{N}$} \\
\hline & & & & & Mild & Severe & \\
\hline $\begin{array}{l}\text { Sort out vowel letters }(\mathrm{a}, \mathrm{e}, \mathrm{i}, \mathrm{o}, \mathrm{u}) \text { from } \\
\text { the letters on the table }\end{array}$ & $\begin{array}{c}3 \\
(25.0 \%)\end{array}$ & $\begin{array}{c}5 \\
(41.7 \%)\end{array}$ & 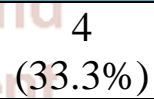 & $\begin{array}{r}0 \\
(0.0\end{array}$ & $\begin{array}{c}8 \\
(66.7 \%)\end{array}$ & $\begin{array}{r}4 \\
(33.3\end{array}$ & 12 \\
\hline $\begin{array}{r}\text { Sort out capital le } \\
\mathrm{f},\end{array}$ & $\begin{array}{c}3 \\
(25.0 \%) \\
\end{array}$ & $\begin{array}{c}6 \\
(50.0 \%)\end{array}$ & $\begin{array}{c}3 \\
(25.0 \%) \\
\end{array}$ & $\begin{array}{c}0 \\
(0.0 \%)\end{array}$ & $\begin{array}{c}9 \\
(75.0 \%) \\
\end{array}$ & $\begin{array}{r}3 \\
(25.0 \\
\end{array}$ & 12 \\
\hline $\begin{array}{r}\text { Sort out small letter } \\
\mathrm{q},\end{array}$ & $\begin{array}{c}2 \\
(16.7 \%) \\
\end{array}$ & $\begin{array}{c}4304 \\
(25.0 \%) \\
\end{array}$ & $\begin{array}{c}6 \\
(50.0 \%) \\
\end{array}$ & $(8.5 \%)$ & $\begin{array}{c}5 \\
(41.7 \%) \\
\end{array}$ & $\begin{array}{c}7 \\
(58.3 \%) \\
\end{array}$ & 12 \\
\hline $\begin{array}{r}\text { Bring out the simi } \\
\text { between let }\end{array}$ & $\begin{array}{c}1 \\
(8.3 \%) \\
\end{array}$ & $\begin{array}{c}5 \\
(41.7 \%) \\
\end{array}$ & $\begin{array}{c}5 \\
(41.7 \%) \\
\end{array}$ & $\begin{array}{c}1 \\
(8.3 \%) \\
\end{array}$ & $\begin{array}{c}6 \\
(50.0 \%) \\
\end{array}$ & $\begin{array}{c}6 \\
(50.0 \%) \\
\end{array}$ & 12 \\
\hline $\mathrm{N}$ & 9 & $\begin{array}{c}19 \\
(39.6 \%)\end{array}$ & $\begin{array}{c}18 \\
(37.5 \%)\end{array}$ & $\begin{array}{c}2 \\
(4.2 \%)\end{array}$ & $\begin{array}{c}28 \\
(58.3 \%) \\
\end{array}$ & $\begin{array}{c}20 \\
(41.7 \%) \\
\end{array}$ & 48 \\
\hline
\end{tabular}

The table above reveals that out of the 12 participants after the formative test $8(66.7 \%)$ had mild difficulties and $3(33.3 \%)$ still had severe difficulties with sorting of vowel letters amongst other letters which shows an improvement from the pre-test with $3(25 \%)$ mild and 9(75) severe at vowel identification.

Also, 9(75\%) had mild difficulties with the identification of capital letters while $3(25 \%)$ still had difficulties with the identification of capital letters. This also shows an improvement from the pre-test where $4(33.3 \%)$ had mild difficulties with $8(66.7)$ having severe difficulties with capital letters.

More so, with regards to sorting of small letters 5(41.7) had mild difficulties while $7(58.3 \%)$ had severe difficulties which shows a significant improvement from the pre-test where $2(25 \%)$ had mild difficulties and 9(75\%) with severe difficulties.

The multiple response set reveals that $(68.8 \%)$ had difficulties by the first formative with (31.3\%) still having severe difficulties working with letters. 
International Journal of Trend in Scientific Research and Development (IJTSRD) ISSN: 2456-6470

\section{Post-Test}

Ability to Work with Letter at Post-Test: Experimental group

\begin{tabular}{|c|c|c|c|c|c|c|c|}
\hline \multirow{2}{*}{$\frac{\text { Ability to Work with Letter }}{\text { Experimental Group }}$} & \multirow{2}{*}{$\begin{array}{l}\text { Very } \\
\text { Mild }\end{array}$} & \multirow{2}{*}{ Mild } & \multirow{2}{*}{ Severe } & \multirow{2}{*}{$\begin{array}{l}\text { Very } \\
\text { Severe }\end{array}$} & \multicolumn{2}{|c|}{ Collapse } & \multirow{2}{*}{$\mathbf{N}$} \\
\hline & & & & & Mild & Severe & \\
\hline $\begin{array}{c}\text { Sort out vowel letters }(\mathrm{a}, \mathrm{e}, \mathrm{i}, \mathrm{o}, \mathrm{u}) \\
\text { the letters on the table }\end{array}$ & $\begin{array}{c}5 \\
1.79\end{array}$ & 6 & $\begin{array}{r}1 \\
8.3\end{array}$ & $\begin{array}{r}0 \\
\left(0.0^{c}\right.\end{array}$ & $\begin{array}{r}11 \\
91.7\end{array}$ & $\begin{array}{c}1 \\
(8.3 \%)\end{array}$ & 2 \\
\hline $\begin{array}{r}\text { Sort out capital } 1 \\
M, \mathrm{f}\end{array}$ & $\begin{array}{c}4 \\
3.3 \%)\end{array}$ & $\begin{array}{r}5 \\
+1.7\end{array}$ & $\begin{array}{c}3 \\
(25.0 \%)\end{array}$ & $\begin{array}{c}0 \\
(0.0 \%\end{array}$ & $\begin{array}{c}9 \\
(75.0 \%)\end{array}$ & $\begin{array}{c}3 \\
(25.0 \%)\end{array}$ & 12 \\
\hline $\begin{array}{r}\text { Sort out small lett } \\
\mathrm{m},\end{array}$ & $\begin{array}{c}3 \\
5.0^{c}\end{array}$ & $\begin{array}{c}3 \\
25.0 \%)\end{array}$ & $\begin{array}{r}5 \\
(41.7\end{array}$ & $\begin{array}{c}1 \\
(8.39\end{array}$ & $\begin{array}{c}6 \\
(50.0 \%)\end{array}$ & $\begin{array}{c}6 \\
(50.0\end{array}$ & 2 \\
\hline $\begin{array}{l}\text { Bring out the } \\
\text { lifferences betwe }\end{array}$ & $\begin{array}{c}2 \\
(16.7 \%)\end{array}$ & $\begin{array}{c}5 \\
(41.7 \%)\end{array}$ & $\begin{array}{c}4 \\
(33.3 c\end{array}$ & $\begin{array}{c}1 \\
(8.3 \%\end{array}$ & $\begin{array}{c}7 \\
(58.3 \%)\end{array}$ & $\begin{array}{c}5 \\
(41.7 \%)\end{array}$ & 12 \\
\hline Multiple & $\begin{array}{c}14 \\
(29.2 \%)\end{array}$ & $\begin{array}{c}19 \\
(39.6 \%)\end{array}$ & $\begin{array}{c}13 \\
(27.1 \%)\end{array}$ & $\begin{array}{c}2 \\
(4.2 \%)\end{array}$ & $\begin{array}{c}33 \\
(68.8 \%)\end{array}$ & $\begin{array}{c}15 \\
(31.3 \%)\end{array}$ & 48 \\
\hline
\end{tabular}

The table above reveals that out of the 12 participants in the experimental group 11(991.78) of them had mild visual discrimination difficulties with the sorting of vowel letters while only $1(8.3 \%)$ of them still had severe visual discrimination difficulties relating to the sorting of capital letters in the post-test. $9(75 \%)$ of them had mild visual discrimination difficulties while $3(25 \%)$ still had severe difficulties in recognizing capital letters.
Besides, for the sorting of small letters $6(50 \%)$ of them had mild visual discrimination difficulties with the sorting of small letters amongst other letters.

For the ability to bring out similarities and differences in letters $7(58.3 \%)$ of them had mild difficulties while $5(41.7 \%)$ others had severe difficulties in bringing out the similarities and differences in letters.

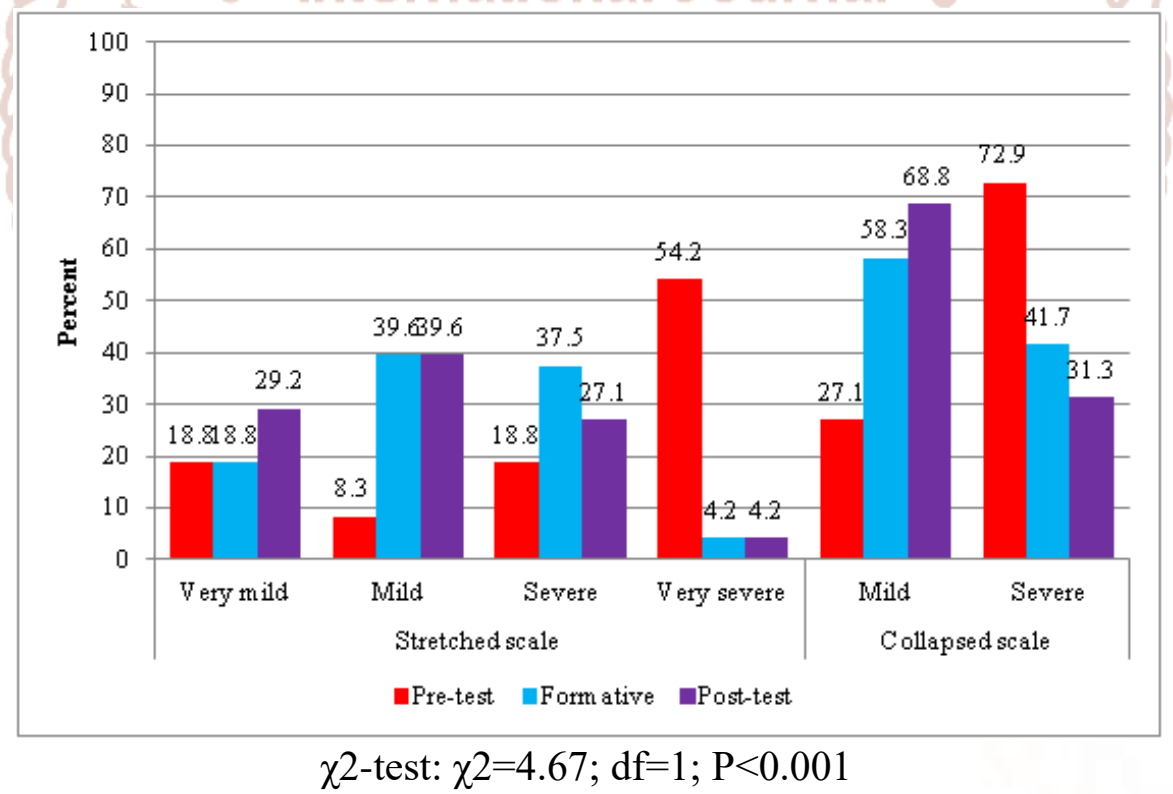

\section{Change in Disability Status in the Experimental Group for Ability to Work with Letter}

There was a significant improvement in the condition of the children in the experimental group. The proportion of children with severe visual discrimination disability decreased from $72.9 \%$ (MRS: $\mathrm{n}_{\text {responses }}=35$ ) at pre-test to 41.7\% (MRS: $\left.\mathrm{n}_{\text {responses }}=20\right)$ at the formative evaluation to $31.3 \%\left(\right.$ MRS: $\mathrm{n}_{\text {responses }}=15$ ) at post-test and this change was very significant $(\chi 2$-test: $\mathrm{P}<0.001)$. 
International Journal of Trend in Scientific Research and Development (IJTSRD) ISSN: 2456-6470

\section{Post-Test}

Ability to Work with Letter at Post-Test: Control Group

\begin{tabular}{|c|c|c|c|c|c|c|c|}
\hline \multirow{2}{*}{$\frac{\text { Ability to work with Letters }}{\text { Control Group }}$} & \multirow{2}{*}{$\begin{array}{l}\text { Very } \\
\text { Mild }\end{array}$} & \multirow{2}{*}{ Mild } & \multirow{2}{*}{ Severe } & \multirow{2}{*}{$\begin{array}{l}\text { Very } \\
\text { Severe }\end{array}$} & \multicolumn{2}{|c|}{ Collapse } & \\
\hline & & & & & Mild & Severe & \\
\hline $\begin{array}{c}\text { Sort out vowel letters }(\mathrm{a}, \mathrm{e}, \mathrm{i}, \mathrm{o}, \mathrm{u}) \mathrm{fr} \\
\text { the letters on the table }\end{array}$ & $\begin{array}{c}5 \\
1.7\end{array}$ & 0 & 1 & $\begin{array}{c}6 \\
(500 \%)\end{array}$ & $\begin{array}{c}5 \\
+1.7 \%)\end{array}$ & $\begin{array}{c}7 \\
(58.3 \%)\end{array}$ & 2 \\
\hline $\begin{array}{r}\text { Sort out capital le } \\
\mathrm{f},\end{array}$ & $\begin{array}{c}3 \\
5.0\end{array}$ & 1 & 3 & $\begin{array}{r}5 \\
1.7\end{array}$ & $\begin{array}{c}4 \\
3.3 \%)\end{array}$ & $\begin{array}{r}8 \\
(66.7\end{array}$ & 12 \\
\hline Sort out small lett & 1 & 1 & $\begin{array}{r}2 \\
6.7\end{array}$ & $\begin{array}{r}8 \\
(66.7\end{array}$ & $\begin{array}{c}2 \\
6.7 \%)\end{array}$ & $(83$ & 12 \\
\hline $\begin{array}{l}\text { Bring out the s } \\
\text { between }\end{array}$ & $\begin{array}{c}2 \\
16.79\end{array}$ & $\begin{array}{r}1 \\
8.3 c\end{array}$ & 2 & $\begin{array}{c}7 \\
(58.3 \%)\end{array}$ & $\begin{array}{c}3 \\
25.0 \%)\end{array}$ & $\begin{array}{r}9 \\
\left(75.0^{\circ}\right.\end{array}$ & 12 \\
\hline Multip & $\begin{array}{c}11 \\
(22.9 \%) \\
\end{array}$ & $\begin{array}{c}3 \\
(6.3 \%) \\
\end{array}$ & $\begin{array}{c}8 \\
(16.7 \%) \\
\end{array}$ & $\begin{array}{c}26 \\
(54.2 \%) \\
\end{array}$ & $\begin{array}{c}14 \\
(29.2 \%)\end{array}$ & $\begin{array}{c}34 \\
(70.8 \%)\end{array}$ & 48 \\
\hline
\end{tabular}

The table above reveals that in the post-test for the control group out of 12 participants $5(41.7 \%)$ had mild visual discrimination problems with sorting out vowel letters while $7(58.3 \%)$ had severe visual discrimination difficulties with vowel letters.

Also, 4(33.3\%) had visual discrimination difficulties with recognition of capital letters while $8(66.7 \%)$ had severe visual discrimination difficulties with the recognition of capital letters.
Besides $2(16.7 \%)$ of them had mild visual discrimination difficulties with sorting of small letters while $10(83.3 \%)$ had severe visual discrimination difficulties in the sorting of small letters amongst other letters.

Regarding their visual discrimination ability to recognize similarities and differences in letters $3(25 \%)$ of them had mild visual discrimination difficulties while $9(75 \%)$ of them had severe visual discrimination problems with letters.

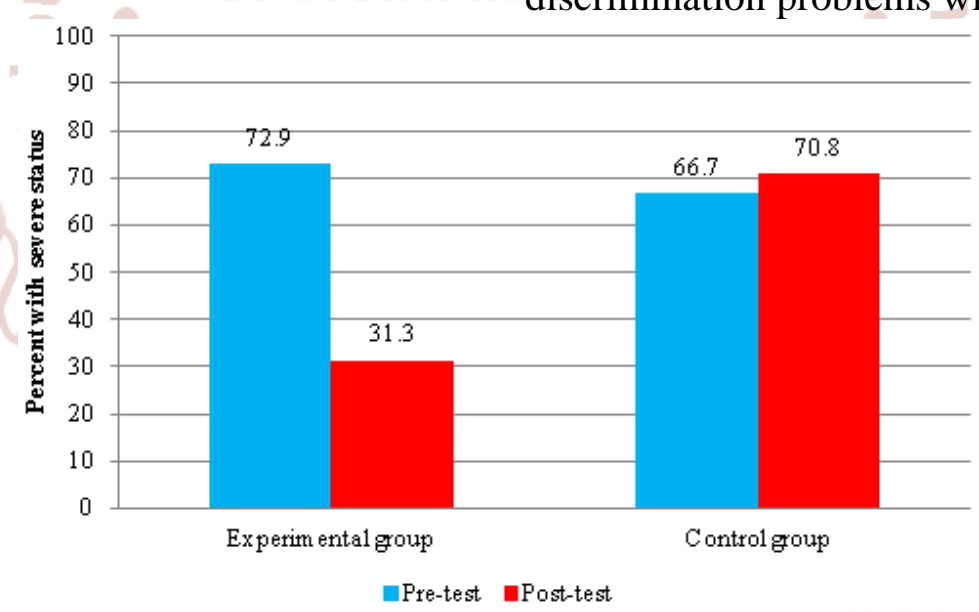

Experimental group: $\chi 2$-test: $\chi 2=4.20 ; \mathrm{df}=1 ; \mathrm{P}=0.040 ;$ Control group: $\chi 2$-test: $\chi 2=0.19 ; \mathrm{df}=1 ; \mathrm{P}=0.665$

Comparing Change in Disability Severity between Pre-Test and Post-Test and within Test Group for Ability to Work with Letters

In the experimental group, from pre-test to post test, it was realized a significant dropped from $72.9 \%$ to
$31.3 \%$ ( $\chi 2$-test: $\mathrm{P}<0.05)$ in the proportion of children with severe disability. Unlike the experimental group, basically no change was observed in the control group though a slight increase from $66.7 \%$ to $70.8 \%$ was observed but this was probabilistically due to chance ( $\chi 2$-test: $\mathrm{P}>0.05)$. 
International Journal of Trend in Scientific Research and Development (IJTSRD) ISSN: 2456-6470

Comparing Progression between Pre-Test and Post-Test for Ability to work with Letters

Comparing Progression between Pre-Test and Post-Test for Ability to work with Letters

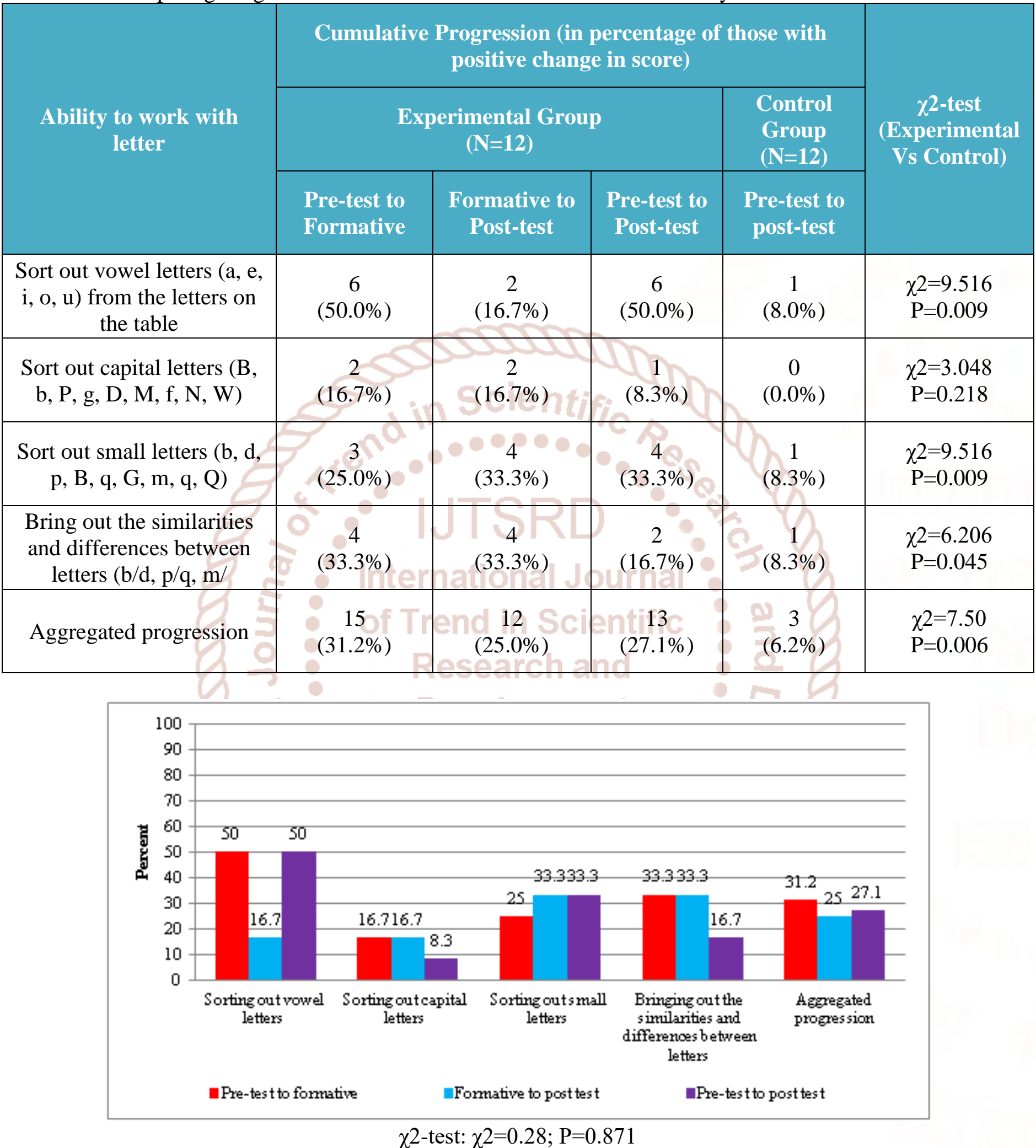

\section{Change in Progression in the Experimental Group for Ability to Work with Letters}

In aggregate, progression was weak. Though there was slight drop, progression was relatively constant $(\chi 2$-test: $\chi 2=0.28 ; \mathrm{P}=0.871$ )across test levels as it was $31.2 \%$ from pre-test to first formative, dropped slightly to $25 \%$ between first formative and post-test and was $27.1 \%$ from pre-test to post-test. 


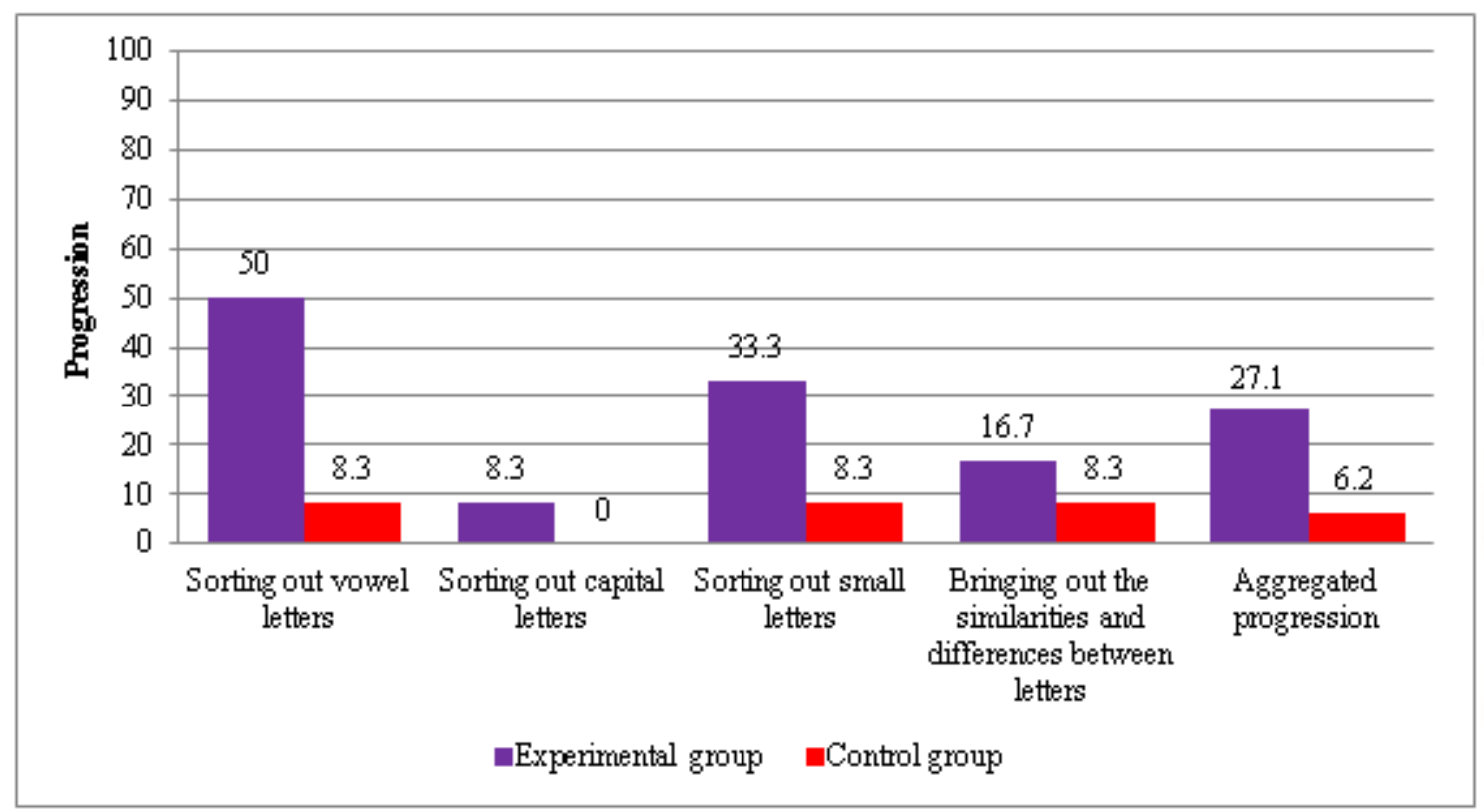

Comparing Progression between Experimental and Control Group for Ability to Work with Letters

Comparing progression between control and experimental group, for all the scales, progression was higher in the experimental group and in aggregate it was $27.1 \%$ in the experimental group as against $6.2 \%$ in the control group and this discrepancy was significant $(\chi 2$-test: $\mathrm{P}<0.05)$.

This research hypothesis sought to confirm or reject if visual discrimination training in the recognition of letters has any effect on reading among struggling readers in primary five in Buea municipality. Four items examined the visual discrimination training on letters recognition on all the scales. Comparing the progression between the experimental and control groups, it was revealed that there was a higher progression with the experimental group in the pretest, teacher made test and post-test at $27.1 \%$ as against $6.2 \%$ in the control group and this discrepancy was significant at $(\mathrm{x} 2$-test: $\mathrm{P}<0.05)$. Therefore, we reject the null hypothesis and retain the alternative. This implies that visual discrimination training on letters recognition has a positive effect on reading among struggling readers in primary five.

Also, the thematic analysis depicting pupils' perception of the difficulties they face with the recognition of letters reveals that out of the 24 participants who were interviewed relating to the recognition of letters the alphabet 19 of them revealed that they could not recognise all the letters of the alphabet while 5 of them admitted they could recognise all.

Besides, when asked if they could differentiate between vowel letters and consonant letters, 7 of them admitted they could while 17 of them said they could not identify all.

Furthermore, when the interview was focused on what one should note in order to be able to read 5 of them said the position of letters and the sound must by noted while 17 of them said one should note letters while 2 of them said it is necessary to note the sounds of the letters

Also, when asked to differentiate between capital letters and small letters 14 of them said they were all letters while 3 of them said they were both capital and small letters then, 7 of them said they were sounds (see appendix).

Comparing the findings of the quantitative and qualitative data, both findings revealed that some struggling readers in primary five have visual discrimination deficit with the identification of letters. This view is supports that of Chard and Osborn (2015) that children with poor visual discrimination skills in letter identification will find difficulties making differences between similar letters like $\mathrm{n}$ and $\mathrm{m} \mathrm{b}$ and $\mathrm{p}$ which is common with struggling readers. In articulating this view Ehri, Nunes and Wilows (2001), hold that children need visual discrimination skill to develop print tracking skills. This will help them to begin to learn some names and sounds of the 
letters of alphabet to develop sight word vocabulary. They stress that parents and teachers should get children involved in writing and producing letter cards and stick them on the walls, so as to read them frequently to create familiarity with letters. They argue that this will help them to develop visual discrimination skills for letters, and to recognise the similarities and differences in letters and in words. The findings of Woodroome and Kethy (2009) indicate that older children have better visual discrimination skills as compared to their younger peers. These authors worked with children aged 5 years and above while the present study involved pupils between 10 and 11 years of specifically primary five because the main interest was to assess how the preparedness or the readiness of the pupils to enter secondary school. Contrasting the two findings strictly might be erroneous, but it is important to note the relatively high ages of the participants of this study who however are still struggling with reading.

\section{Conclusion}

This study was out to investigate the effect of visual discrimination training in reading on the recognition of items in primary five in the Buea municipality. It was guided by theories. The magnocullular deficit theory by Stein and Walsh 1997, the social constructivist theory by Vygotsky 1920. It was a quasi-experimental study carried out in a natural classroom environment three schools were involved in the study selected through stratified random sampling technique. 24 participants 18 boys and 6 girls were used, selected through a multi-stage sampling technique (teacher nomination, observation of progress record and an oral reading test) to be certain that the nominees were actually struggling readers. The participants were divided into the experimental and control group at randomly. Each group had 12 participants 8 from each school. The experimental group received the treatment that was provided by the researcher for 8 weeks while the control group did not.

$>$ Four instrument were used in the study. The master sheet for reading assessment, test score sheet, interview guide for pupils and an interview guide for teachers. Data was analysed and presented descriptively on tables frequencies, percentages and figures. Inferentially it was analysed using the S.P.S.S 21.0 using the chisquare test of independence. Finding revealed a positive progression with the experimental group in all scales. This implies that visual discrimination training has positive effects on reading among struggling reader.

\section{REFERENCES}

1. America Psychological Association, (2016). Reading instruction changes the brain. Retrieved on July $8^{\text {th }} 2014$ at 7.20 am fromwww.apa.orglactionไresources $\backslash$ research-inactionไreading. apsa.

2. Amin, M. E. (2005). Social science research: Conception, methodology and analysis. Kampala: Makerere University Printery.

3. Arky, B.(2014).Understanding visual processing issues. Retrieved on June $14^{\text {th }} 2015$ at 7.30amfrom https://www.understood.org/en/learning-attentionissues/child-learning-disabilities/visual

processing. Understanding Visual Processing Issues.

4. Breakwell, G. M., Hammond, S. And FiffeSchaw, C. (2004).Research methods in psychology. London: Sage Publications.

5. Burns, P. C, Roe, B. D. and Ross, E. P. (1996). Teaching reading in today's elementary school. $7^{\text {th }}$ Ed. Boston: Houghton Mifflin.

6. Burroughs, R. (2014). Simple Visual Discrimination Training for a Child with Autism and Exceptional Learning Difficulties (2014).Honours Theses. Paper 2512, Western Michigan University. Retrieved on July $8^{\text {th }} 2016$ at

7.40amfrom

http://scholarworks.wmich.edu/honors_theses.

7. Chard, D. J. and Osborn, J. (2015).Phonemics and word recognition instruction in early reading programmes. Guidelines for accessibility: Reading rocket. Retrieved on July $8^{\text {th }} 2015$ at $8.20 \mathrm{am}$ from www.reading rockets.orglarticle/phonics-andword recognition-early reading programesguideline-accessibility.

8. Christensen, C., Horns, M. and Johnson, C.(2010). Disrupting class: How disruptive innovations will change the way the world learns. Boston: McGraw Hills Companies.

9. Clutten, S. C. (2009). The development of visual perception test for learners in the foundation phase. Retrieved on April $12^{\text {th }} 2014$ at 9.20amfromuir.unisa.ac.za/bitstream/handle/1050 0/2613/thesis_clutten_s.pdf? 
10. Cohen, L., Manion, L. and Morrison, K.(2007). Research Methods in Education. London and New York: Routledge

11. Cusimance, A. (2007). Visual discrimination: Noting differences in frequently misperceived words. Retrieved on July $26^{\text {th }} 2014$ at 7.30 amfrom www.amazon.com/usual/ discrimination differences frequently $\quad-\quad$ misperceived /dp/0972776222.

12. Dauksas, L. and White, J. (2008).Discovering shapes in Pre-school. Teaching Young Childern.Vol.7 No.4Retrieved on July $8^{\text {th }} 2014$ at 9.20am from www.naeyc.org/tyc/article/shapesspace.

13. Ehri, L. C., Nunes, S. R.and Willows, D. M. (2001).Systematic phonemic instruction helps students learn to read: Evidence from the national reading pane's meta-Analysis, Education research, 71 (3), 393-447

14. Erikson, E. (1950). Childhood and society. New York: Morton. Retrieved on March $8^{\text {th }} 2015$ at 7.20amfrom www.amazon.com / Childhood Society -Eric- H-Erikson / dp/ 039331068 X.

15. Fraenkel, J. R. And Wallen, N. E. (2006). How to design and evaluate research in education. New York: McGraw-Hill Companies.

16. Gagne, M. B. (2007). Skills necessary for proficient reading. National reading panels. Teaching Children to Read. Retrieved on July $8^{\text {th }}$ 2015 at 0 7.50amfrom www.nationalreachingpanel.org/ publications/summary.htm

17. Gall, M. D., Gall, J. P. and Borg, W. R. (2015). Applying Educational Research: How to Read, Do, and Use Research To Solve Problems of Practice, Loose-Leaf Version with Marketing Brochure CY2015, 7th Edition. New York: Longman.

18. Gambrel, L. B. and Pressley, M. (2003). Effective reading instruction. Retrieved on October $14^{\text {th }}$ 2015 at 6.30amfrom https://www.pearsonhighered.com/assets/Hip-UsPearhighered/Simple-Chapter/0132963507.pdf.

19. Gangwer, T. (2010). Visual discrimination: Visual teaching alliance. Retrieved on February $20^{\text {th }} 2015$ at 7.00amfrom www.online.org.article 19296.

20. Garnette, K. (2010).What are classrooms like for students with learning disabilities. Retrieved on
October $14^{\text {th }} 2015$ at $4.30 \mathrm{am}$ from w.w.w. readingrockets, org/Article/What-are-classroomsstudents-learning-disabilities.

21. Heward, W. L. (2003). Struggling readers: What consultants needs to know. Journal of educational and Psychological, consultation 15(2) 191204.Retrieved on July $8^{\text {th }} 2014$ at 7.20am fromhttp:www.readinggate.netljournal $\backslash 10474412 . j$ ournal of educational and psychological consultation.

22. Hoss, V. (2014). Importance of reading skills. International news. Retrieved on February $24^{\text {th }}$ 2015 at 7.20amfrom http:/ everyday life. Global Post. Com/Importance.

23. Hundt, K., (2013). Reading and Visual discrimination: Breakthrough in learning blog. Retrieved on April 14 2016 at 9.30am from w.w.w.get your breakthrough.com $\backslash$ blog $\backslash$ bid $\backslash 293058$ \reading-andvisual discrimination.

24. Hurst, M. (2003). Theory of cognitive development. Retrieved on February $24^{\text {th }} 2015$ at 8.50amfrom study. Com/ academy/ lesson/levvygotsky's-theory - of - cognitive development.htm/.

25. Ihenacho, I. J. (2010). Inclusive education in higher education: A keynote address on the investiture of the UNESCO Chair at the University of BUEA, Cameroon,26 May, 2010.

26. Ihenacho, I. J. (1998).Reading readiness diagnostic test instrument: Department of special education and rehabilitation sciences. University of Jos.

27. Kelly, C. and Campbell, L.(2012).Helping struggling readers. Retrieved on April 20 2015 at 10.00amfrom education.jhu.edu/pd/newhorizonsstrategies/topics /literacyarticles/helpingstrugglingreaders.

28. Kurtz, L. A. and Net Library (2006). Visual perception problems on children with $\mathrm{AD} / \mathrm{HD}$, autism and other learning disabilities. A guide for parents and professionals. London. Jessica Kingsley Publisher. Retrieved on April $24^{\text {th }} 2015$ at

9.10amfromwww.sydney.edu.au/compass/docume nts/visual-discrimination-facts.pdf.

29. Lake, W. S., Eskridge, D. and Perry, L.(2000).Reading the cornerstone to success. 
International Journal of Trend in Scientific Research and Development (IJTSRD) ISSN: 2456-6470

Retrieved on April 23 ${ }^{\text {rd }} 2015$ at 10.10am from www Learning disabilities-readingtutor.com|reading process.htm|.

30. Laurice, J (2002). Best practices in planning interventions for students with reading problems. Retrieved on July $8^{\text {th }} 2014$ at 7.20am from www.readingrockets.orglarticlelbest-practicesplanning-interventions-students-reading-problems.

31. Laurice, J. (2004). Reading: Encouraging positive attitudes: Strategies for parents and teachers. Ohio: Ohio State University

32. Law No 2010/002 of 13/4/2010 Relating to the protection and welfare of persons with disabilities

33. Marling, C. D. And Paugh, P. (2004).A classroom teacher's guide to struggling readers. Retrieved on June $26^{\text {th }} \quad 2014 \quad$ at $8.20 \mathrm{am}$ fromhttp://books.google.cm/bookd/about/A_classr oom-Teachers-s-Guide-to struggling readers.htm/?id=WGCQAQAAMAAJ^ ${ }^{\wedge}$ redir-esc $=$.

34. Mcleod, S. B. (2007). Simple psychology. Retrieved on July $14^{\text {th }} 2014$ at 8.00 amfrom www. Simple psychology. Org/ vygotsky.htm/.

35. McMillan, J. H. (1996). Educational Research. Fundaments for the consumer. Harper Collins College Publisher: New York.

36. Moats, L. And Tolman, C. (2009). Reaching disabilities. Retrieved on July $24^{\text {th }} 2014$ at 8.30amfrom www.reading rockets.org/article. 28749 .

37. Morrow, L. M. Gambrel, L. B. and Pressley, M. (2003). Best Practices in literacy instruction. New York: The Guilford press.

38. Nana, C. (2015). Research methods and applied statistics: Beginners and advanced learners. Buea: GOOAHEAD.

39. National Centre for Learning Disability (2013). The power of hope to learn and succeed. Retrieved on June $26^{\mathrm{h}} 2014$ at 8.00amfrom www.ncld.org/types-learning - destabilizes/ auldrelated -issues/visual-processing- disorder/ on 26/6/2014.

40. National Institute of Child Health and Human Development (NICHHD) (2007).Report of the National Reading Panel. Teaching children to read. An evidence based assessment of scientific research literature on reading and its implications for reading instruction. Report on subgroup (NIH) no 00-4769. Washington, D. C: Government.

41. Nsamenang, A. B., Tchombe, T. M. S., Kelller, H. and Fulop, M. (2013). Across- cultural psychology: An Africentric perspectives. Limbe: Design House.

42. Nsamenang, A. B. and Tchombe, T. M. S. (2011). Handbook of African educational theories and practices, A Generative Teacher Education Curriculum. Yaounde: Presses Universitairesd'Afrique

43. Nunan, D. (2003).Practical English Language Teaching. Boston: McGraw Hill companies.

44. Nwazuoke,I. A. (2000).Professional Preparation of Teachers of Exceptional Children for Inclusive Contexts. The Exception Child, 4 (1), 34-35.

45. OT Mom Learning (2009) Visual discrimination activities. Retrieved on December $24^{\text {th }} 2014$ at 9.00amfrom www.ot.mom.learningactivities.htm/--specificdelaysymptoms.

46. Patino, E. (2017). Types of test for reading, writing and Math. Understood for learning and attention issues. Retrieved on July $8^{\text {th }} 2014$ at 7.20am from www.understood.org/en/schoollearning/evaluations/types-of-test/types-of-testfor-reader-writing and maths.

47. Pearson Education (2014).Pearson integrated HSM common core correlations. Retrieved on July $8^{\text {th }} \quad 2014 \quad$ at 7.20 am from www.Pearsonschool.com/..Pearson\%20 integrated $\% 20 \mathrm{HSM} \%$

48. Picciano, A. (2017). Educational Research Primer (Continuum Research Methods). Retrieved on July $8^{\text {th }} \quad 2015$ at 7.20 am from http://www.anthronypicciano.com/sampling/htlm/

49. Pyschohawks (2010). Theories of Cognitive Development: Lev Vygotsky. Retrieved on July $14^{\text {th }} \quad 2014 \quad$ at 9.30 amfrom https:Ilpsychohawks:wordpress.com/2010/09/05/t heories-of-cognitive-dev'tlev-vygotsky.

50. Renee, T.(2013).Visual discrimination: The role of visual discrimination on reading and writing. Retrieved on July $23^{\text {rd }} 2014$ at 8.10amfrom www.schoolsparks. com/take-agoodlook.tipsforhoningvisualdiscrimination.

51. Renee, T(2013). Early childhood development and visual discrimination skills. Retrieved on July $26^{\text {th }}$ 
International Journal of Trend in Scientific Research and Development (IJTSRD) ISSN: 2456-6470

2014

at

8.15amfrom

www.schoolsparks.com/early-childhood-

development/visual discrimination.

52. Rongione, D. (2000).Problems with number recognition kindergarten.e-how-contributor. Retrieved on July $8^{\text {th }} 2014$ at 7.20am from http:Ilwww.e-how.comlinfo.8340197\problemnumber-recognitio-kindergarten.html.

53. Ryan, M. (2004).Social and emotional problems related to dyslexia. Retrieved on February $20^{\text {th }}$ 2015 at 8.00amfrom www.don/ine.org/article/19296.

54. Sceniak, M. P., Chatterjee, S. and Callaway, E. M. (2006). Visual spatial summation in macaquegeniculocortial afferents. Journal of neurophysiology, $96 \quad(6), 3474-3484$ : Dol:10.1152/Jn.00734.2006.

55. Shadish, W. E., Cook, T. D. and Campbell, D. T. (2002).Experimental and quasi-experimental designs for generalised casual inference. New York: Houghton Mifflin Company.

56. Shillcock, T. J. and Scott, InM. (2015). Magnocellular pathway. Advanced vision. Retrieved on February $14^{\text {th }} 2015$ at 9.20 amfrom www.advancedvisiontherapycentre.con/service/as sessments/neuro-optometric-

assessment/magnocellular pathway on $14 / / 2 /$ 2015.

57. Shuttleworth, M. (2008).Quasi-experimental design. Retrieved on November $12^{\text {th }} 2014$ at 9.10amfrom Explorable.com: https://explorable.com/quasi-experimental-design.

58. Singleton, C and Henderson L. M.(2006).Visual factors in reading. London Review of Education, 4 (1), 89-98.

59. Skottum, B. C (2000). The magnocellular deficit theory of Dyslexia; The evidence from contrast sensitivity. Vision Research, 40 (1) 111-127.

60. Skottun, B. C (2010). On the conflicting support for magnocellular deficit theory of dyslexia. Trends in Cognitive Science, 4 (6)211-212.

61. Smith, D. D. and Tyler, N. C. (2010). Introduction to special education: Making a difference. Library of Congress Cataloguing - U.S.A. Publication data.

62. Snowling, M. J and Hulme, C. J. (2006). The Science of reading handbook. Oxford: Blackwell.
63. Snowling, M. J. (2001). From language to reading and dyslexia. Retrieved on May 23 2015 at 9.00amfrom

onlinelibrary.wiley.com/doil10/002dys.85.

64. Stein, J. and Walsh, V. (1997).The Magnocellular deficit theory. Retrieved on June $13^{\text {th }} 2014$ at 10.00amfrom

http://www.2020true.com/office/box-

b/documents.

65. Stein, J. and Walsh, V. (1997). To see but not to read. The magnocellular theory of Dyslexia. Trends in Neuroscience, 20(4)147 - 152.

66. Stein, J. (2001). The magnocelluar deficit theory of developmental dyslexia Jan- Mar;7 (1): 12-36. Retrieved on July $14^{\text {th }} 2014$ at 7.20am. www.pubmedpmid;11305228.

67. Stein J. (2014).Dyslexia: The role of vision and visual attention. Springer: Current developmental report: (14):267 -280. Retrieved on July $8^{\text {th }} 2014$ at

7.20amfrom

http:Ilw.w.w.ncbi.nlm.nih.gov.pubmed.

68. Tambo, L. I. (2003). Principles and methods of teaching: Applicable to Cameroon Schools. Buea: Anucam.

69. Tchombe, T. M. S (2013).Perspectives in indigenous Africa and Western education and Learning, in Tchombe, T. M. S., Nsamenang, A. B, Keller and Fulop, M(2013)Editors CrossCultural Psychology. An Africentric perspectives. Limbe: Design House.

70. Tchombe, T. M. S. (2014). Psychological Parameters in Teaching. Yaounde: Presses Universairesd'Afrique.

71. Thibault, M. and Walbert, D.(2007).Reading images: An introduction to visual literacy. Retrieved on April 12 2015 at $1.20 \mathrm{pm}$ from www.learn.ne.orglip $\backslash$ pages $\backslash 675$.

72. Torgesen, J., Houston, D., Rissman, L. And Kasanonh, K. (2007). Teaching all students to read in elementary schools. A guide for principals. Portsmouth, NH: RMC. Research Corporation, centre on instruction. Retrieved on July $27^{\text {th }} 2014$ at 10.10amfrom www. centre on instruction.org.(IEJEE).

73. UNESCO (2005).Guidelines for inclusion. Ensuring Access to Education for All. Paris: UNESCO. 
74. UNESCO (2007). Advocacy kid for promoting multilingual education/ Including the Excluded. Paris: UNESCO

75. UNESCO (2008). Education in Cameroon statistics on school enrolment, Paris: UNESCO.

76. Van-Hiele, P. (2012). Mind map for Van Hiele model of geometric thought. Elearning. Retrieved on October $3^{\text {rd }} 2014$ at 10.20am from wwwgogeometry.com\mindmaplvan/hielle/geome try-level.html.

77. Vygotsky, L. (1978). Simple Psychology. Retrieved on June $17^{\text {th }} 2014$ at 9.20amfrom www.simple psychology org/vygotsky.htm/.

78. Vygotsky, L. (1920).Social cognitive theory of development. Retrieved from www.simplepsychology.orglvygotsky.html on the 17/6/2014.

79. Wagner, C. (2015) Reading Activities. Retrieved on July $8^{\text {th }} 2014$ at 7.20 amfrom www.triumphantlearning com/15-readingactivities

80. Warren, H., Wheelock, N. and Silvaroli, J.(2010).Visible language: An independent scholar journal Retrieved on July $11^{\text {th }} 2014$ at 8.50amfrom http:IVisible language journal.com.

81. Woodrome, S. E. and Kathy, E. J.(2008). The role of visual discrimination in the learning to read process. An interdisciplinary journal,v22n2p117131Retrieved on April $14^{\text {th }} 2014$ at 7.20amhttp://www.researchgate.net/publicationin-the-learning to read process.

82. Woodrome, S. E. and Kathy, E. J.(2007). Reading and Writing: An Interdisciplinary Journal, V22n2 P117-131. Retrieved on April $15^{\text {th }} 2014$ at 7.20amfromeric,ed.gov $\backslash$ ?idequalll E1825342.

83. Woodrome, S. E. and Kethy E. J. (2009). Visual discrimination: school sparks kinder garden readiness. Retrieved on July $8^{\text {th }} 2014$ at 7.20amfromhttp://visiblelanguage journal.com.web/abstract labs.

84. World Bank Report (2014). Cameroon Economic Update: "Revisiting the Sources of Growth" The Quality of Basic Education, 7.

85. Yuh, E. (2014).AJOSE: Supporting the classroom teacher to understand and teach diverse learners in the classroom. African Journal of Special Education, (AJOSE). (2), 81 01, .1-8. 